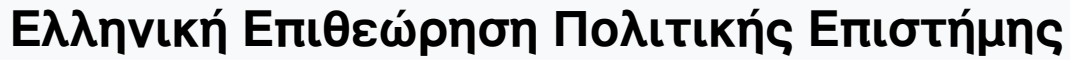

Tó 30 (2007)

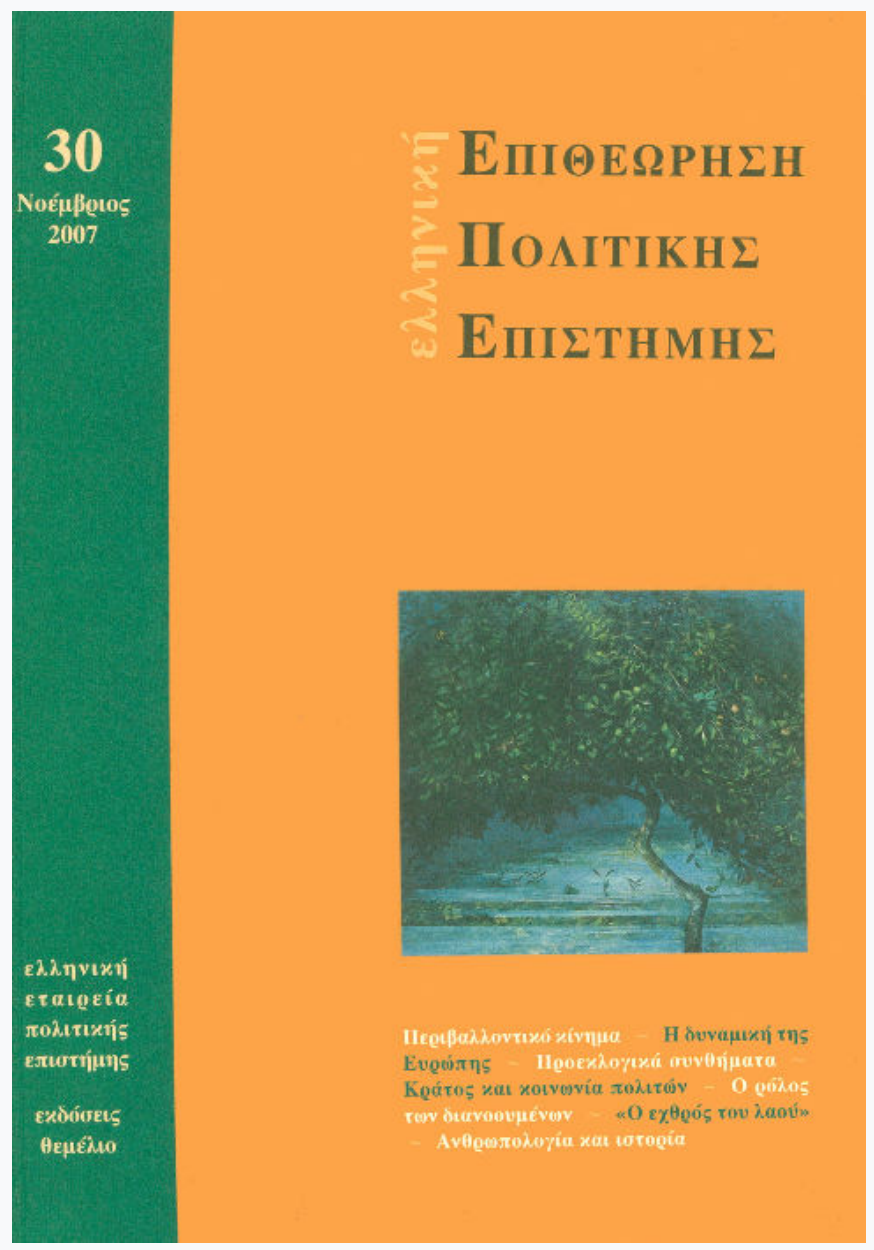

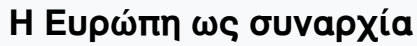

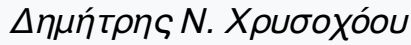

doi: $\underline{10.12681 / h p s a .14426}$

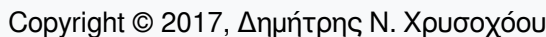

\section{(9) $(1)(0)$}

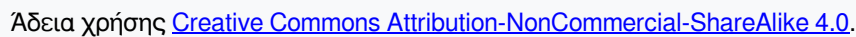

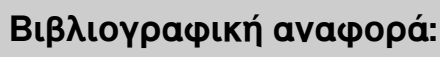

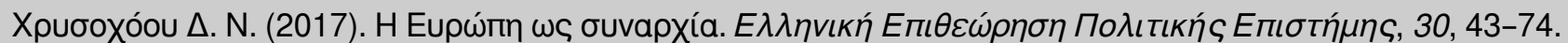
https://doi.org/10.12681/hpsa.14426 


\section{$\mathrm{H}$ EYP $\Omega \Pi H \Omega \Sigma \Sigma Y N A P X I A$}

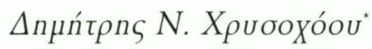

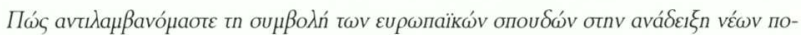

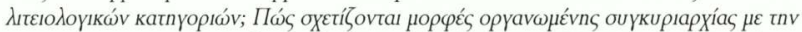

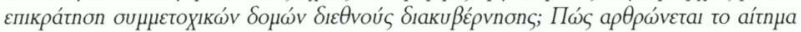

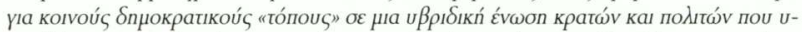

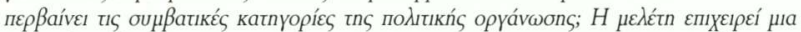

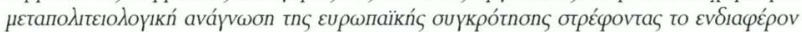

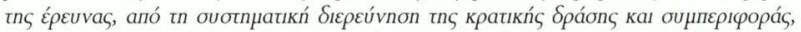

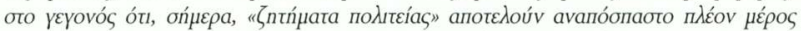

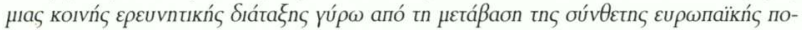

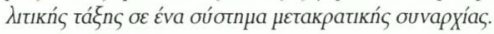

\section{NEE $\Sigma$ AФETHPIE $\Sigma$}

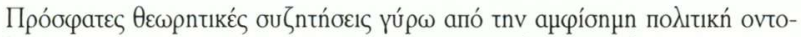

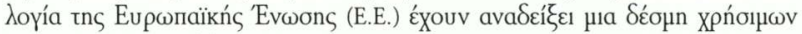

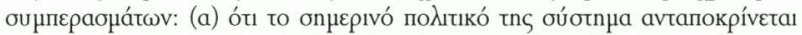

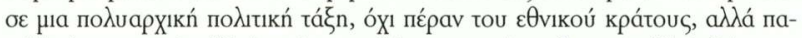

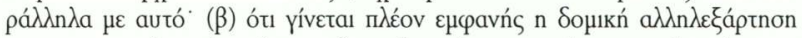

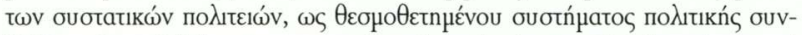

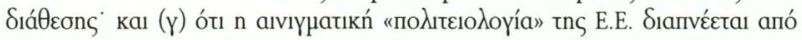

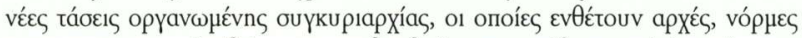

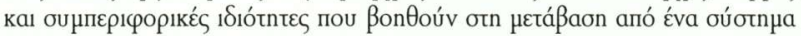

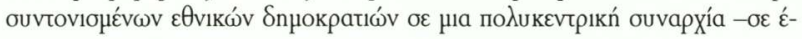

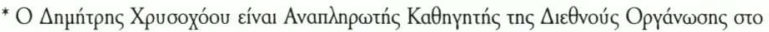

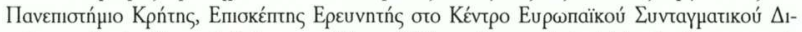

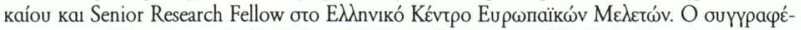

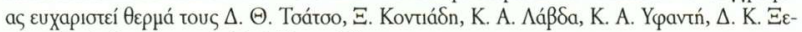

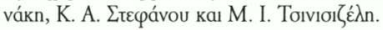




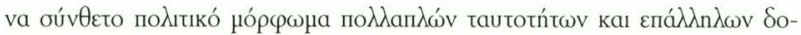

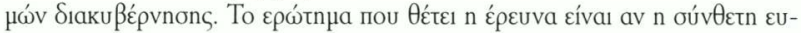

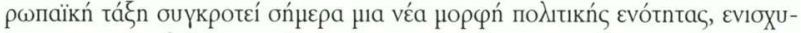

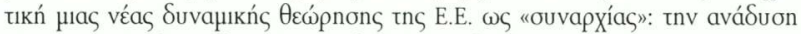

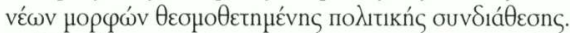

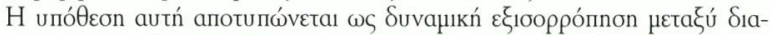

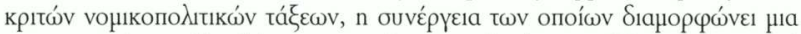

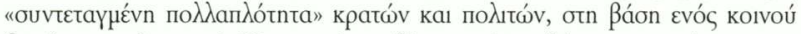

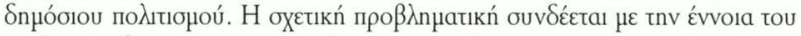

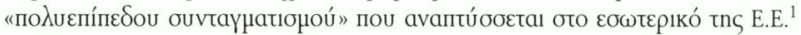

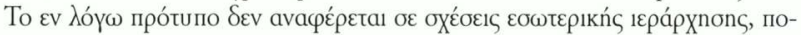

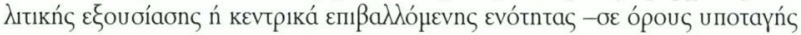

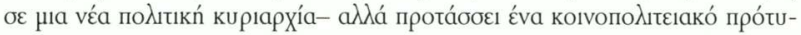

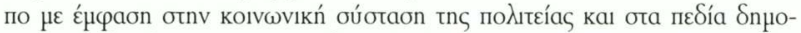

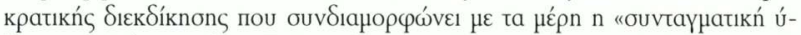

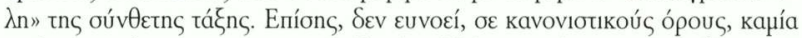

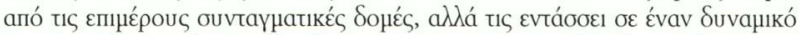

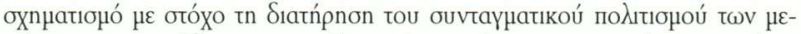

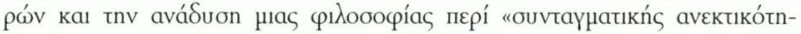

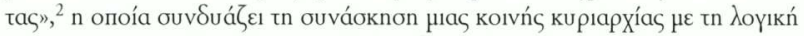

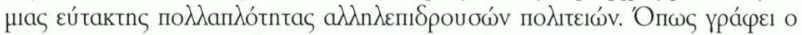

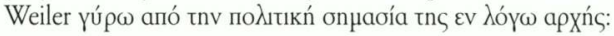

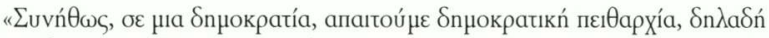

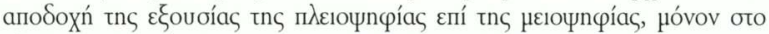

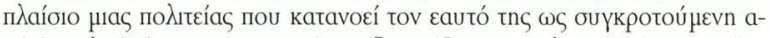

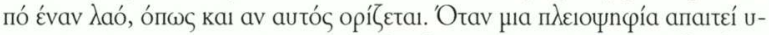

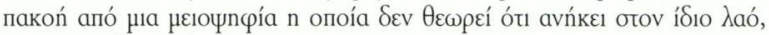

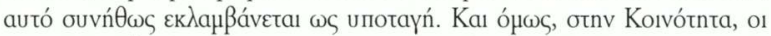

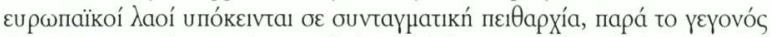

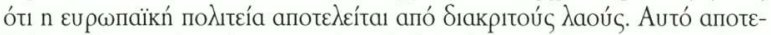

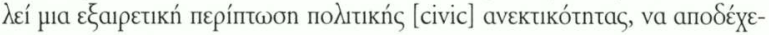

1. J. Shaw, "Postnational constitutionalism in the European Union", Journal of European Public Policy, tóp. 6, тx. 4, 1999.

2. J. H.H. Weiler, «In defence of the status quo: Europe's constitutional Sonderweg», бто J. H. H. Weiler - M. Wind (впц.), European Constitutionalism Beyond the State, Cambridge University Press, Cambridge 2003, o. 15. 


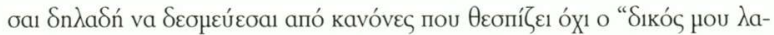

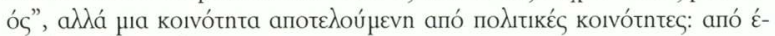
vav גaó á $\lambda \lambda \omega v »{ }^{3}$

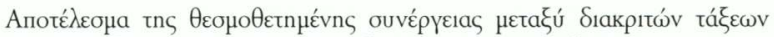

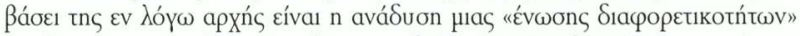

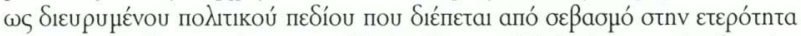

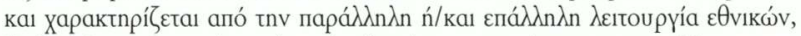

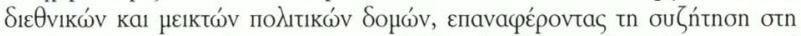

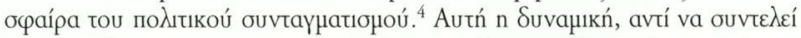

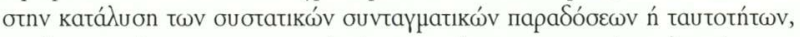

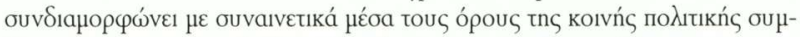

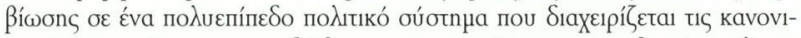

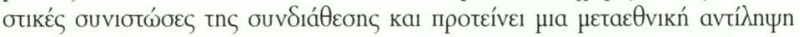

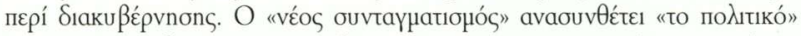

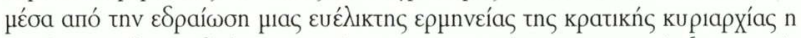

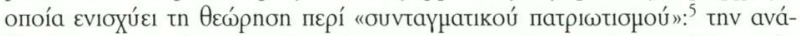

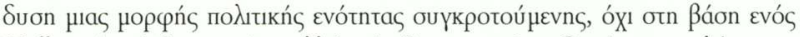

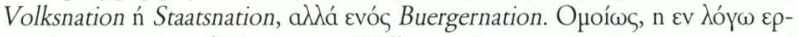

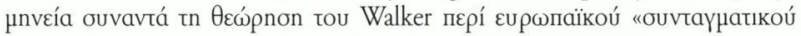

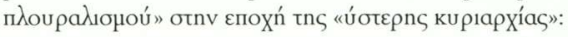

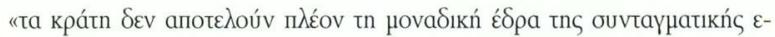

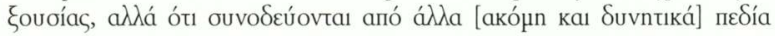

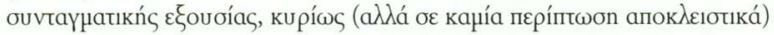

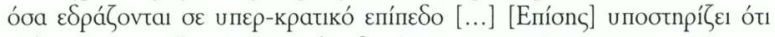

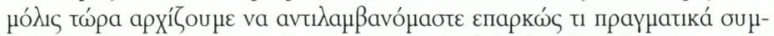

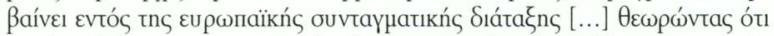

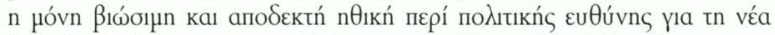

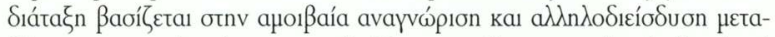

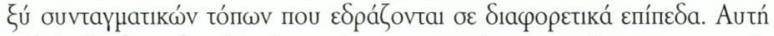

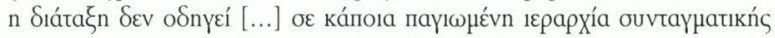

\section{J.H.H. Weiler, ó.п., о. 20-21.}

4. R. Bellamy, Political Constitutionalism: A Republican Defence of the Constitutionality of Democracy, Cambridge University Press, Cambridge 2007.

5. J. Habermas, «The European Nation State - Its Achievements and Its Limits. On the

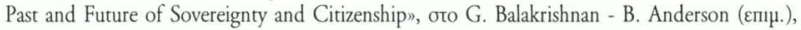

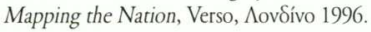




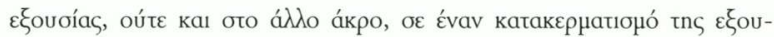
ó́as....".

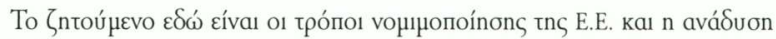

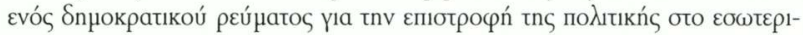

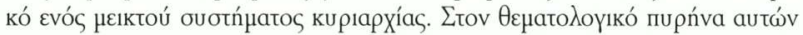

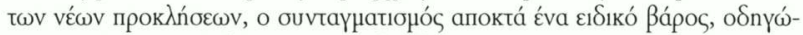

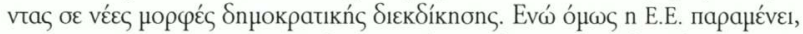

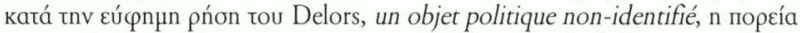

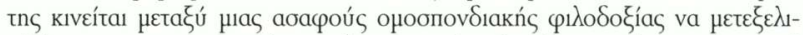

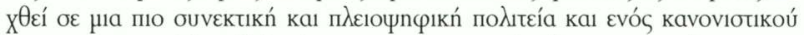

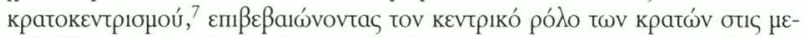

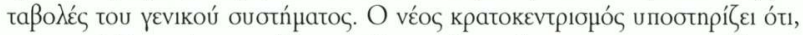

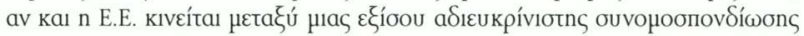

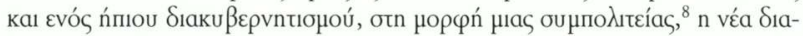

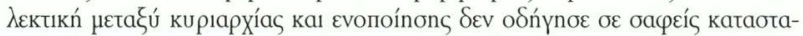

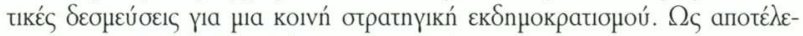

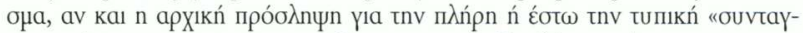

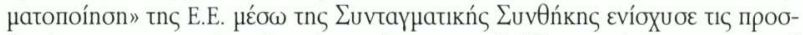

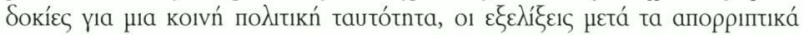

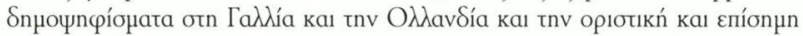

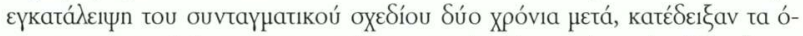

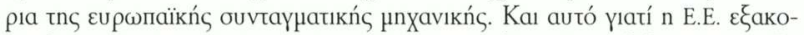

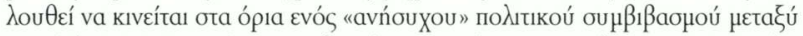

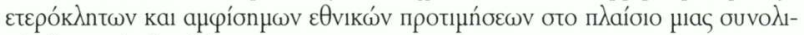

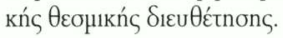

6. N. Walker, "Late Sovereignty in the European Union», oro N. Walker (єпц.),

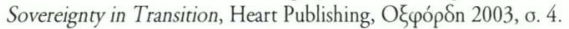

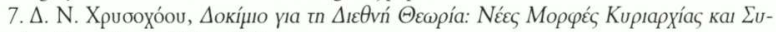
vapXíac, Папаگńons, AӨńva 2006.

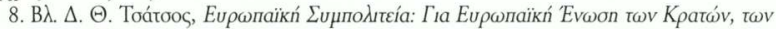

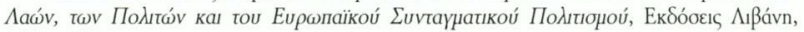
A日ńva 2007. 


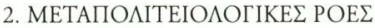

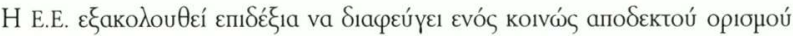

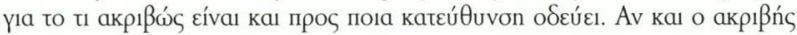

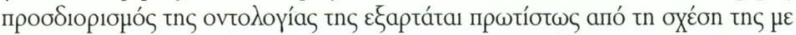

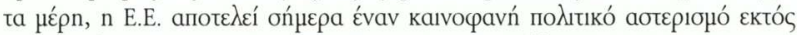

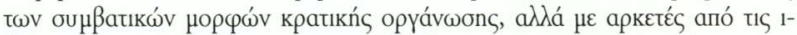

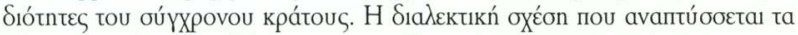

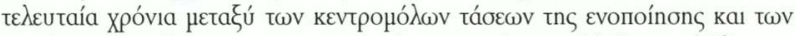

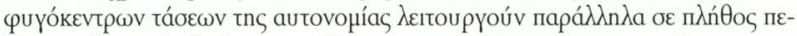

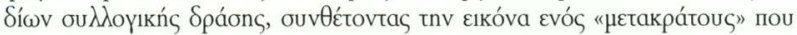

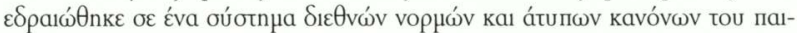

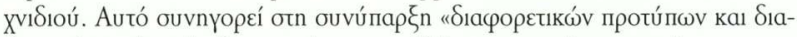

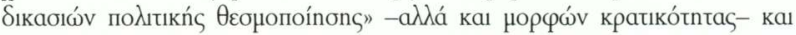

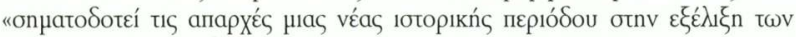

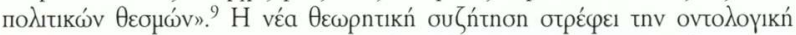

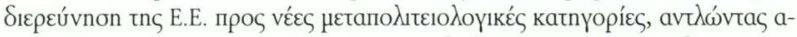

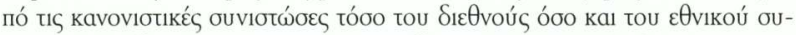

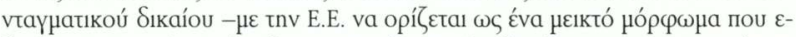

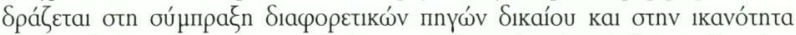

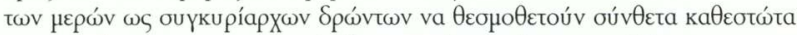

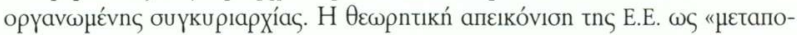

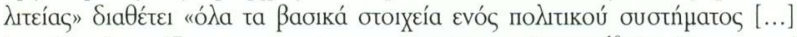

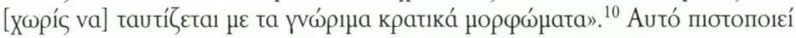

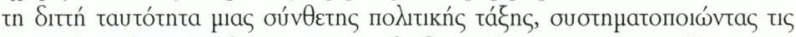

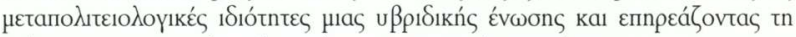

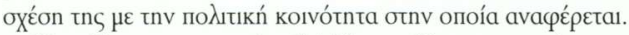

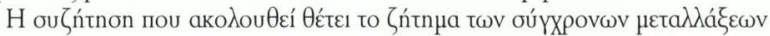

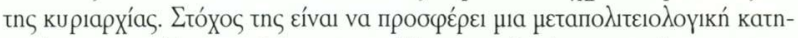

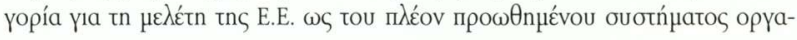

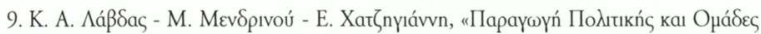

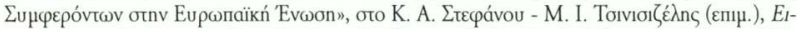

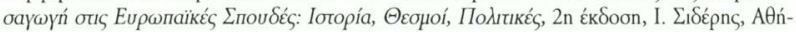
va 2006.

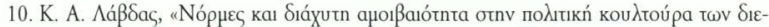

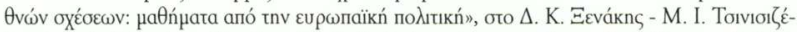

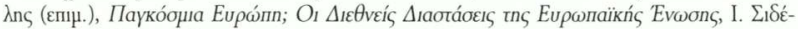
pnc, AAńva 2006, б. 95. 


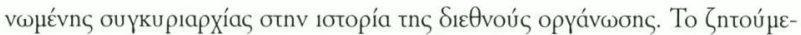

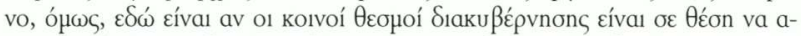

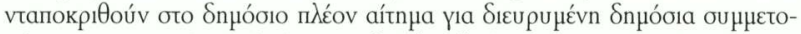

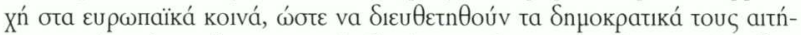

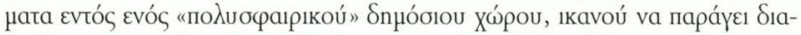

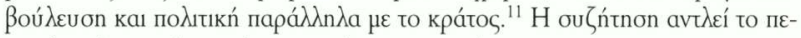

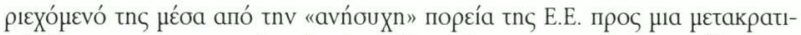

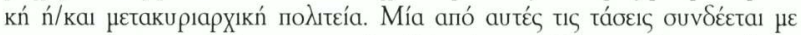

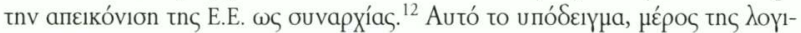

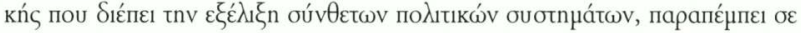

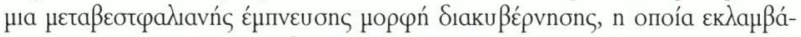

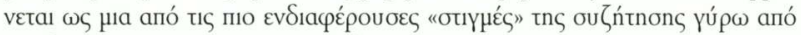

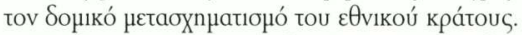

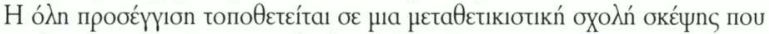

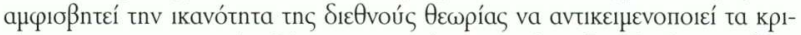

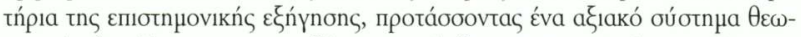

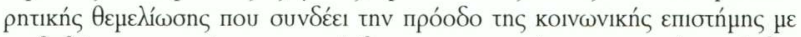

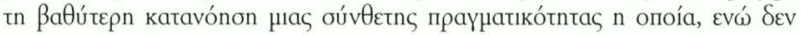

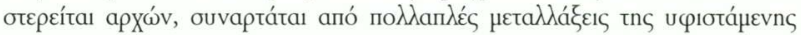

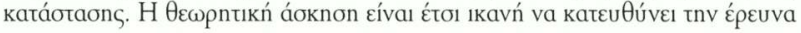

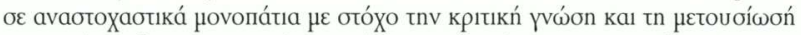

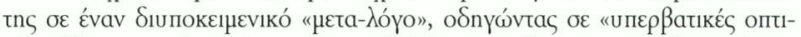

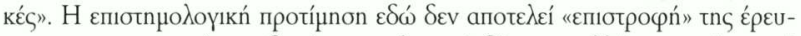

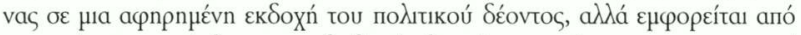

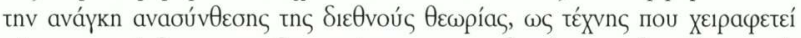

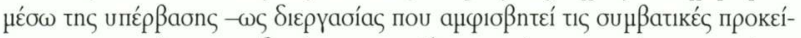

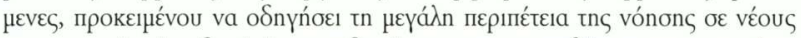

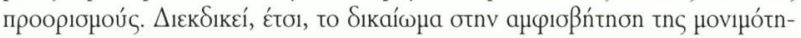

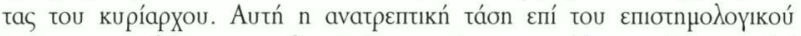

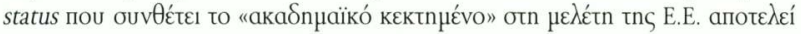

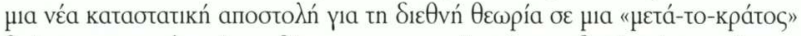

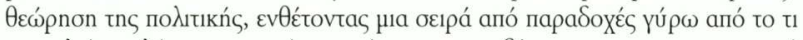

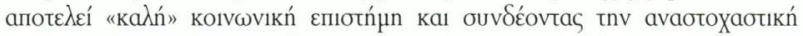

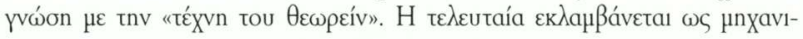

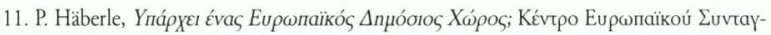

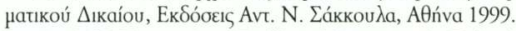

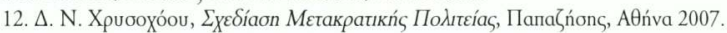




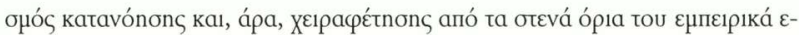

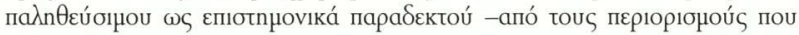

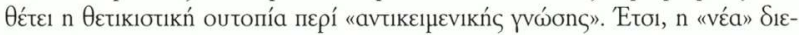

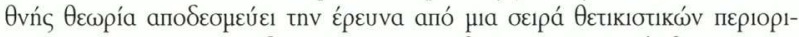

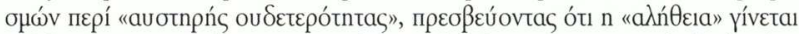

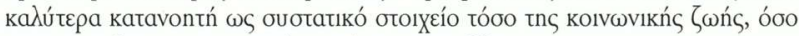

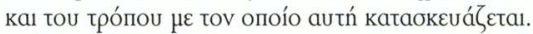

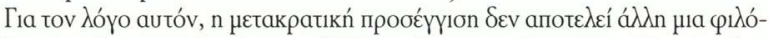

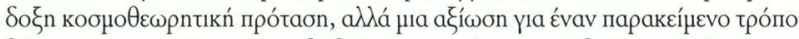

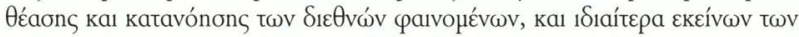

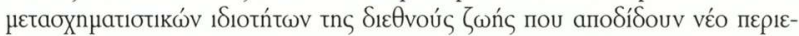

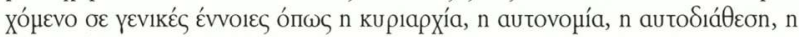

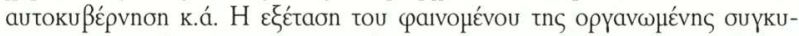

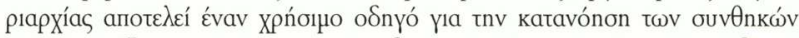

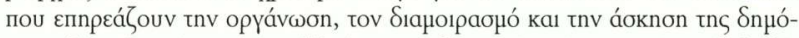

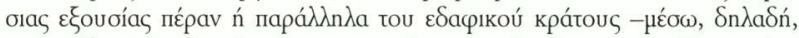

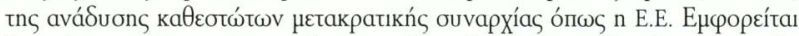

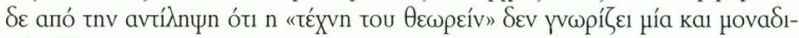

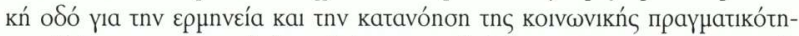

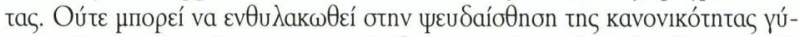

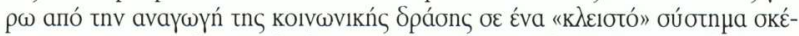

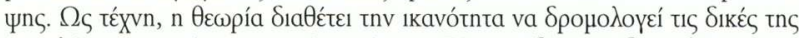

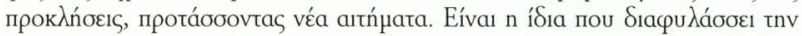

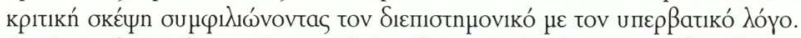

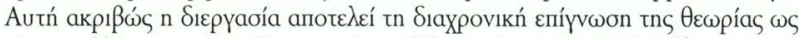

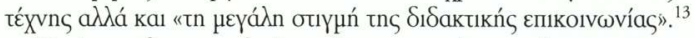

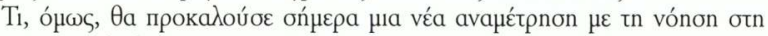

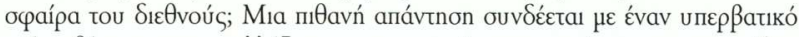

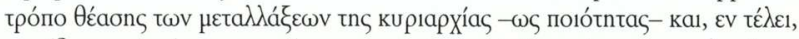

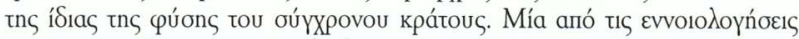

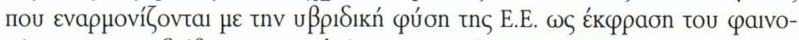

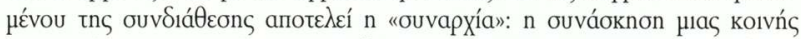

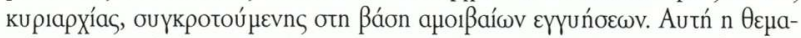

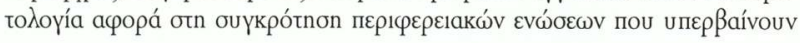

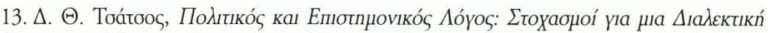

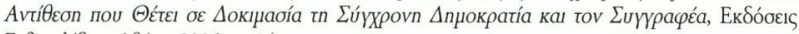

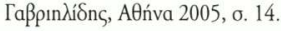




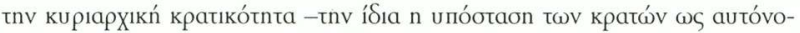

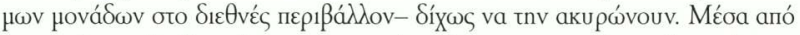

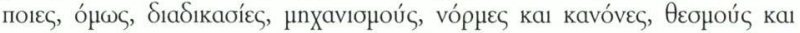

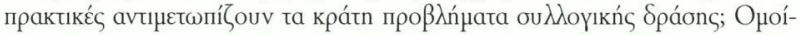

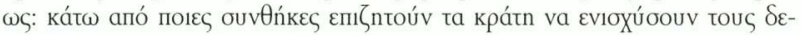

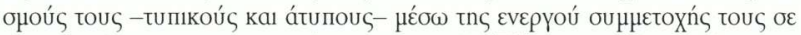

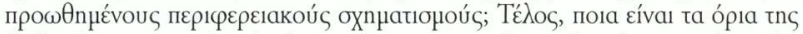

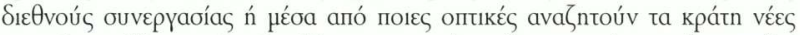

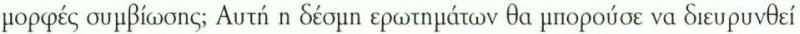

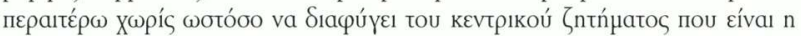

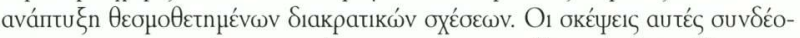

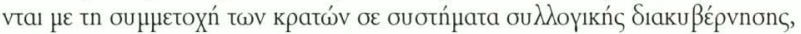

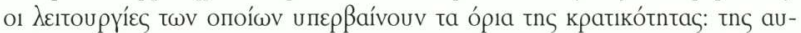

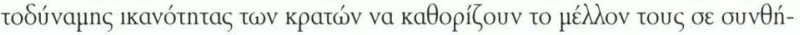

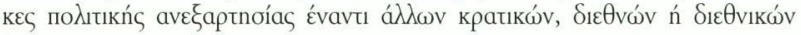
$\delta \rho \omega ́ v \tau \omega \mathrm{v}$.

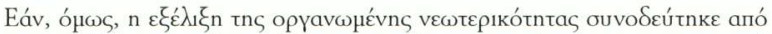

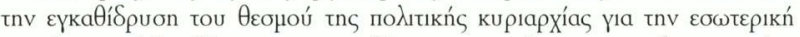

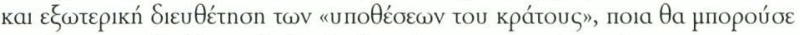

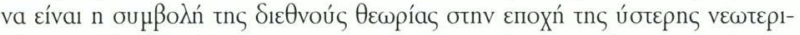

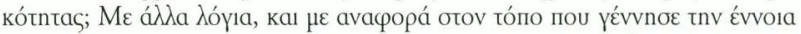

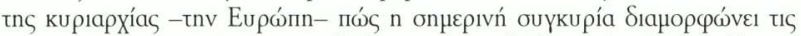

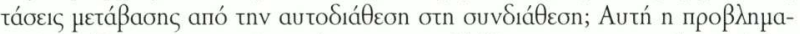

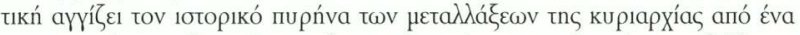

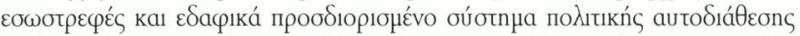

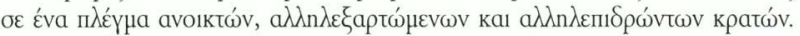

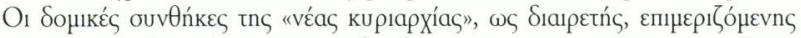

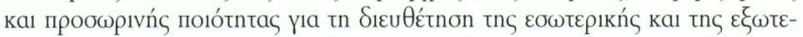

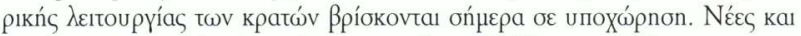

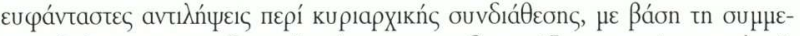

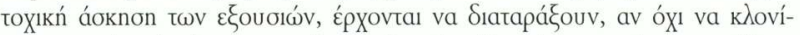

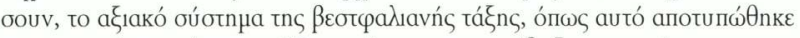

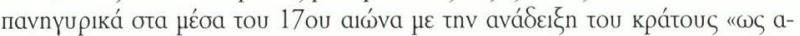

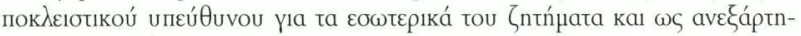

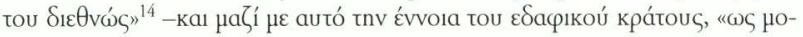

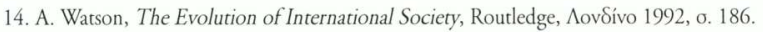




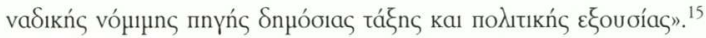

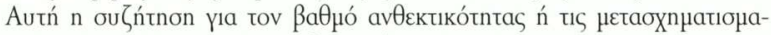

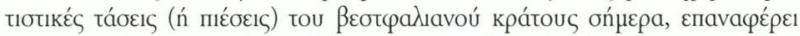

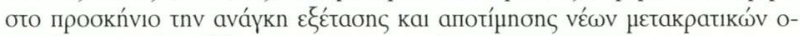

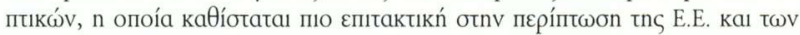

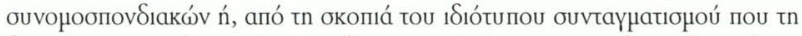

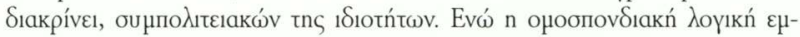

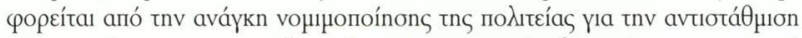

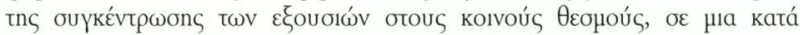

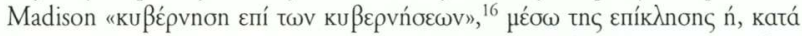

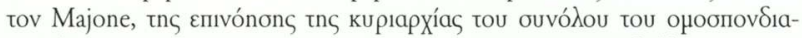

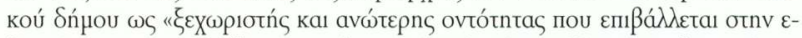

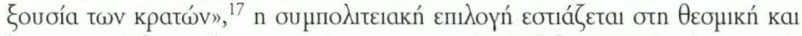

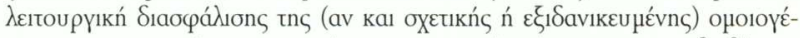

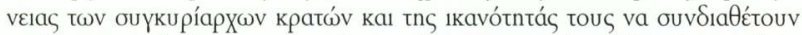

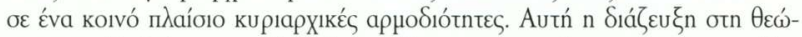

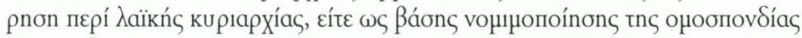

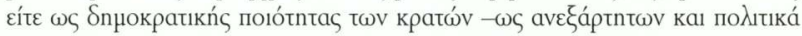

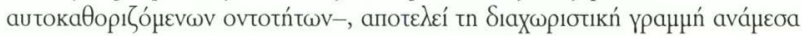

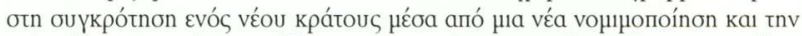

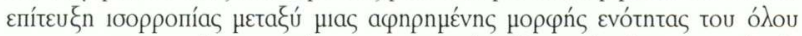

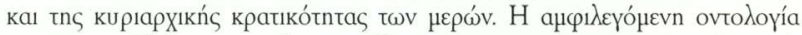

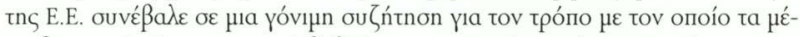

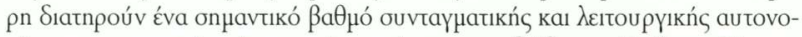

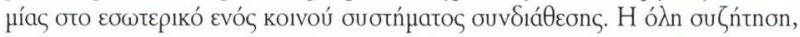

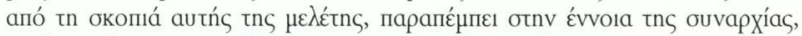

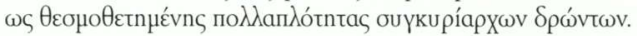

15. M. Burgess, «Federalism», ото A. Wiener - T. Diez (єпц.), European Integration

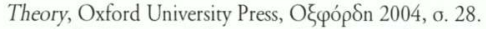

16. G. Majone, Dilemmas of European Integration: The Ambiguities and Piffalls of

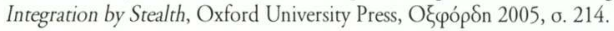

17. Bג. E.S. Morgan, Inventing the People: The Rise of Popular Sovereignty in England

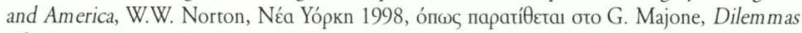
of European Integration, ó.п., о. 214. 


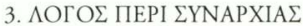

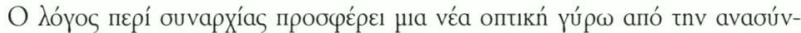

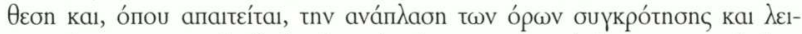

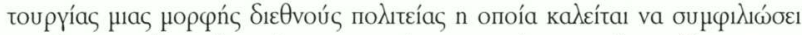

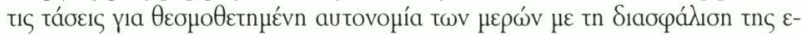

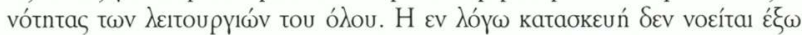

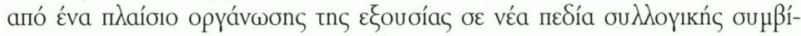

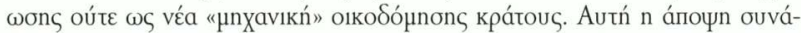

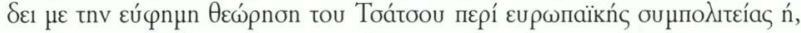

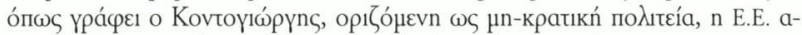

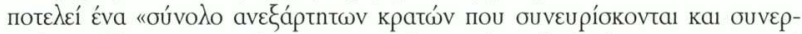

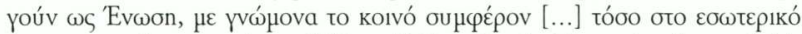

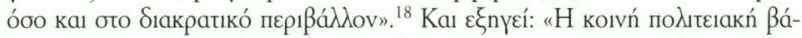

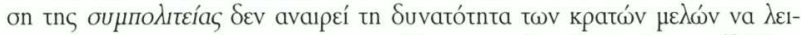

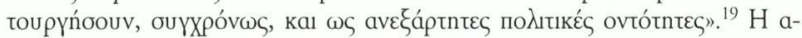

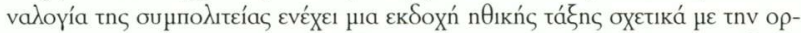

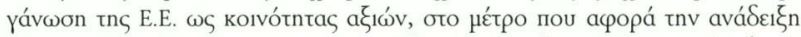

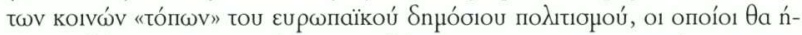

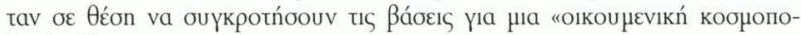

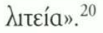

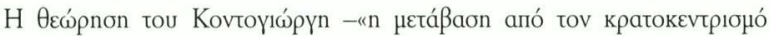

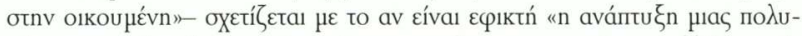

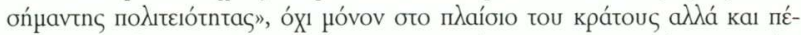

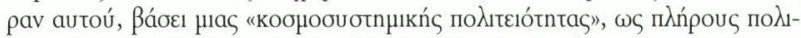

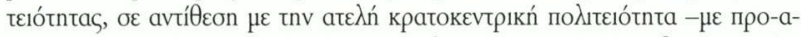

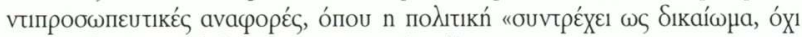

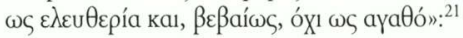

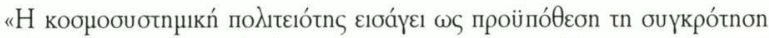

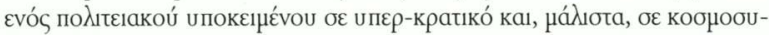

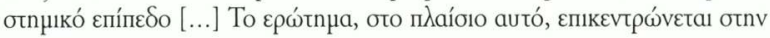

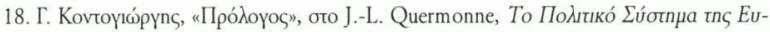

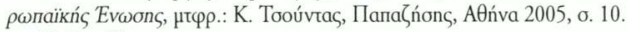

19. ¿to ísı.

20. ¿to ísio.

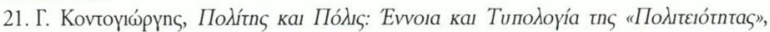

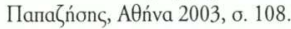




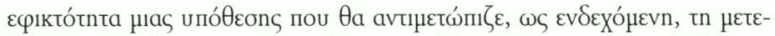

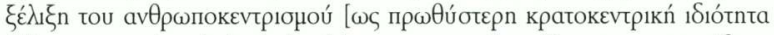

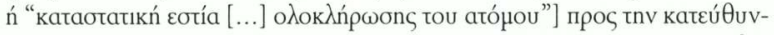

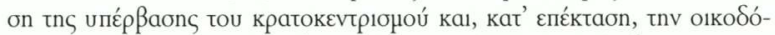

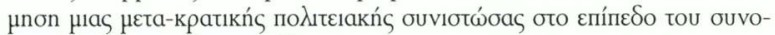

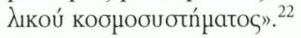

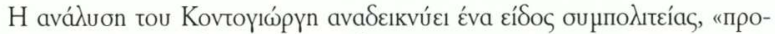

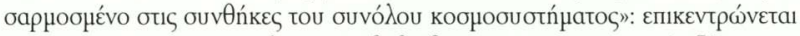

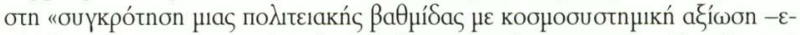

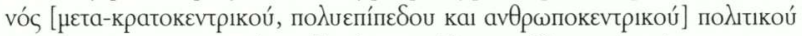

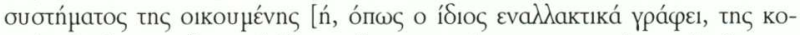

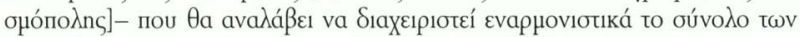

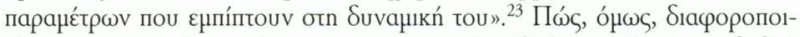

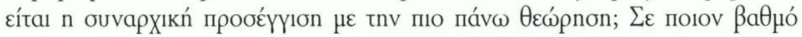

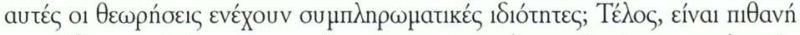

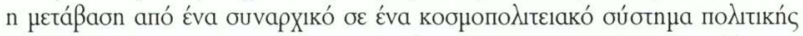

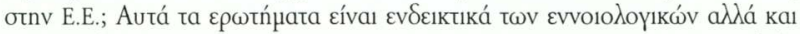

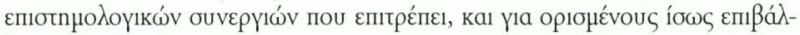

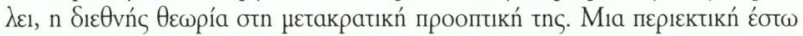

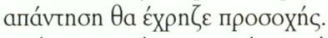

Ava

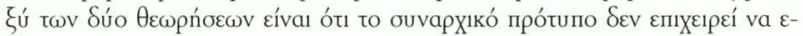

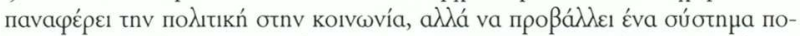

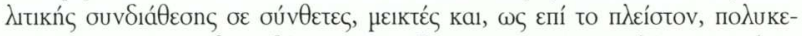

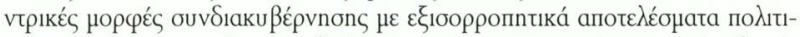

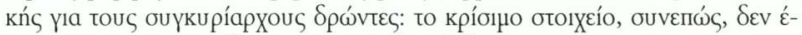

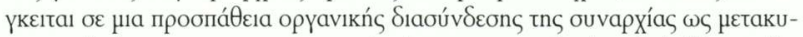

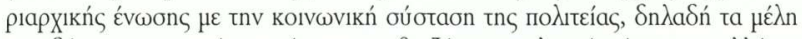

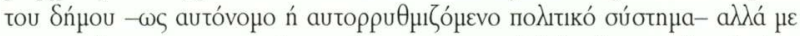

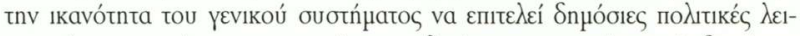

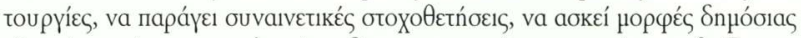

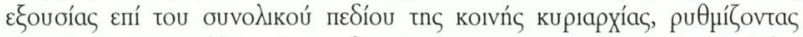

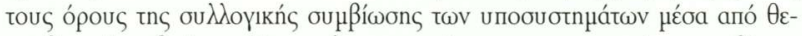

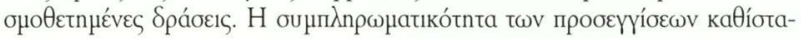

22. Nto ísio, o. 104-105.

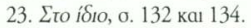




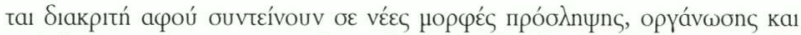

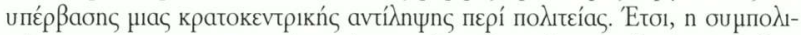

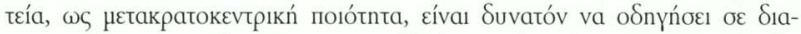

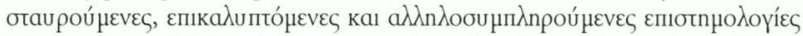
үứ

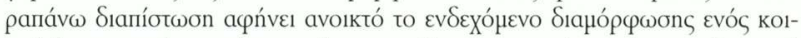

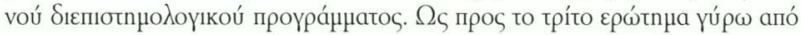

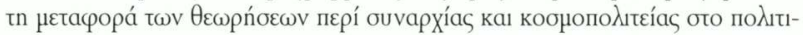

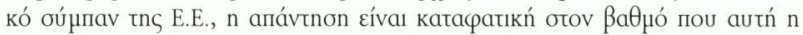

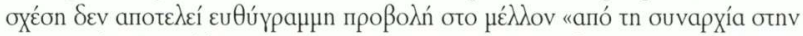

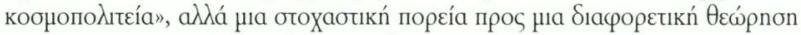

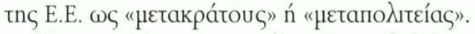

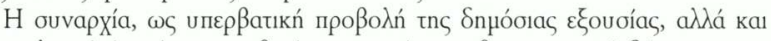

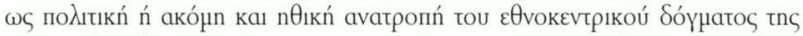

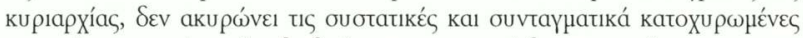

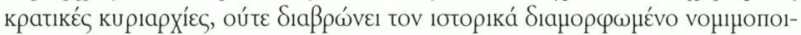
ntikó touৎ pó

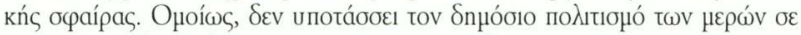

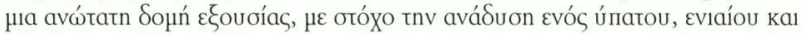

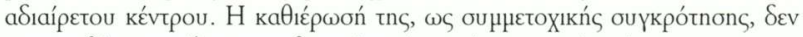

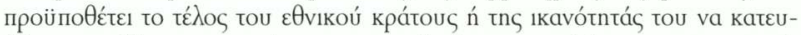

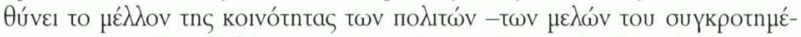

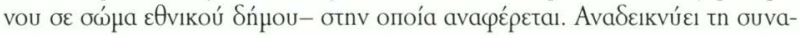

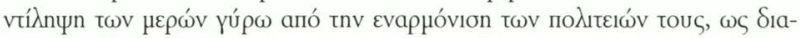

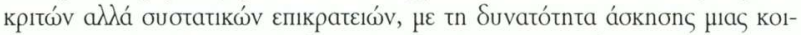

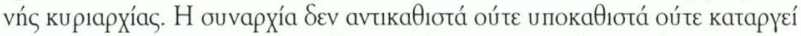

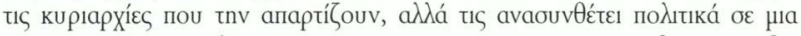

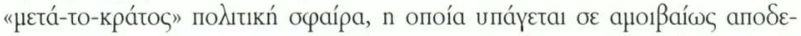

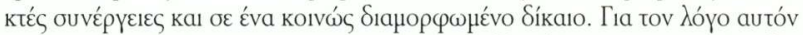

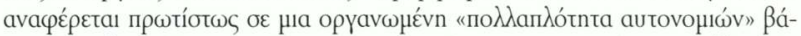

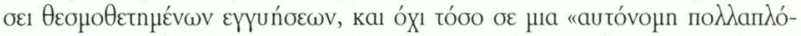

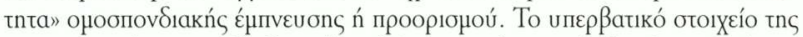

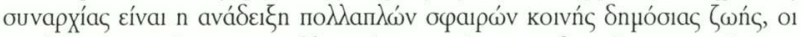

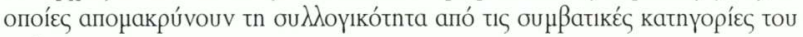
кра́тоus.

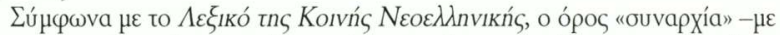

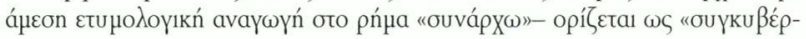




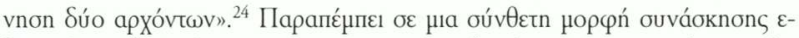

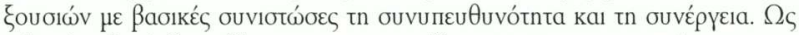

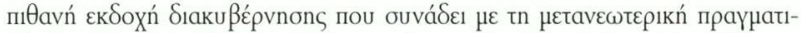

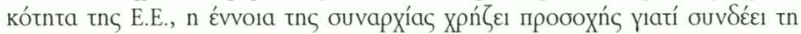

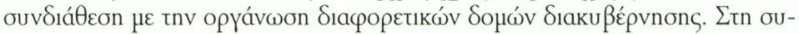

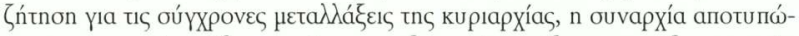

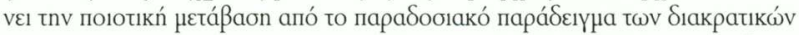

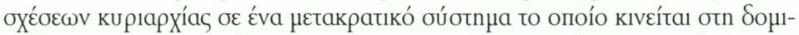

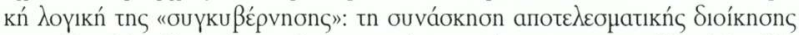

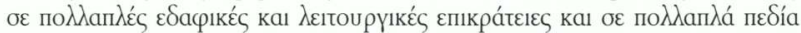

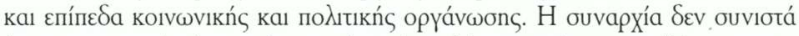

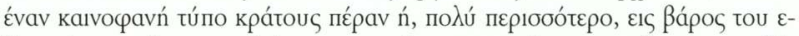

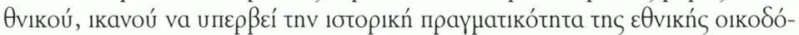

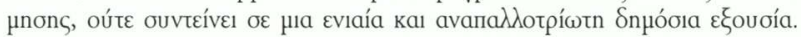

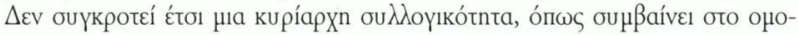

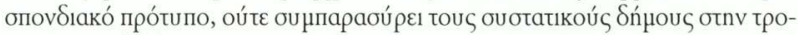

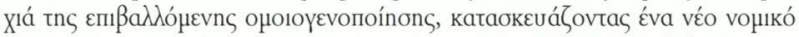

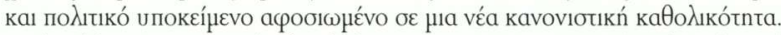

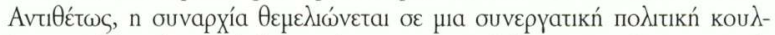

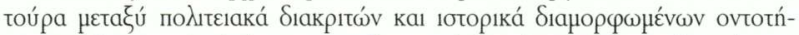

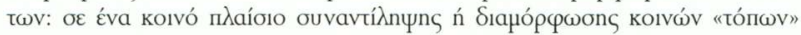

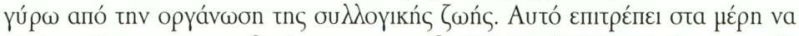

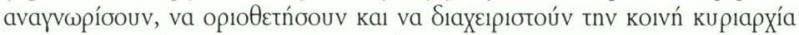

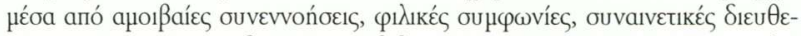

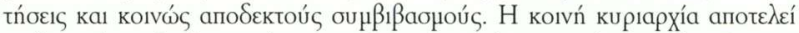

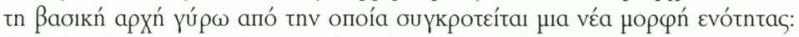

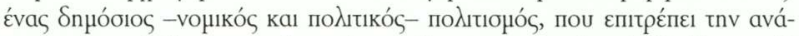

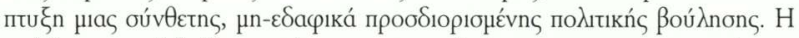

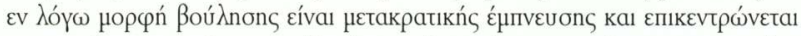

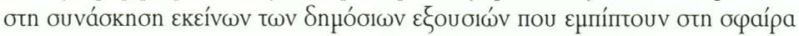

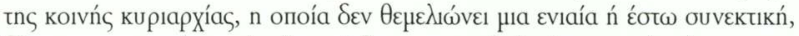

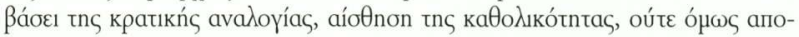

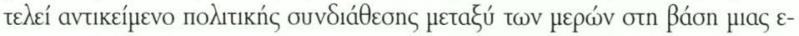

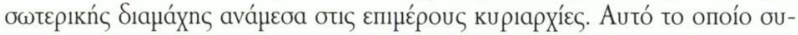

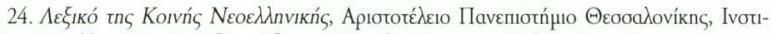

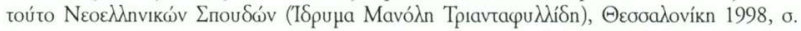
1287. 


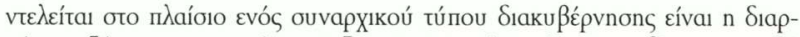

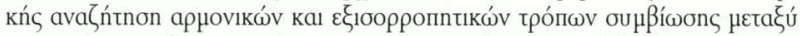

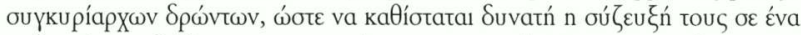

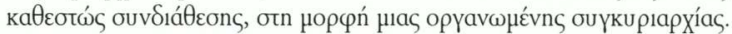

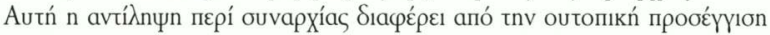

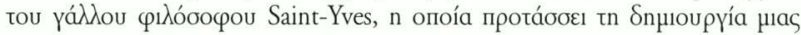

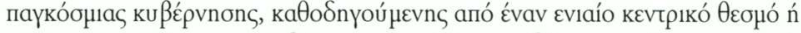

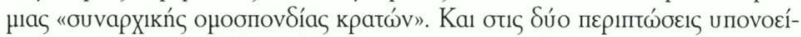

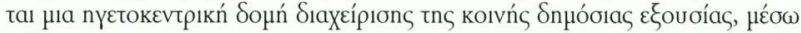

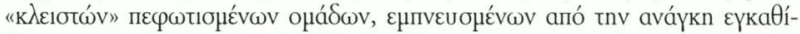

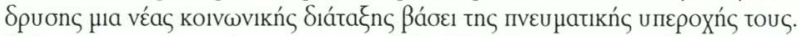

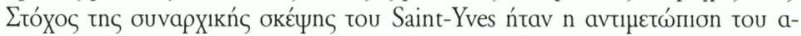

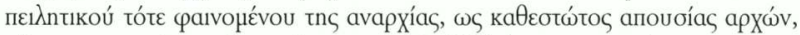

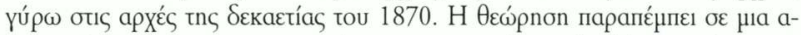

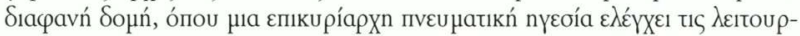

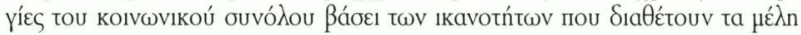

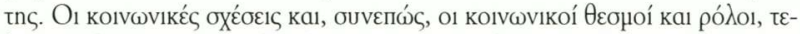

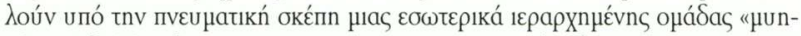

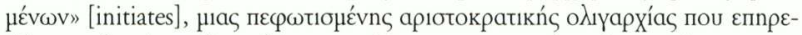

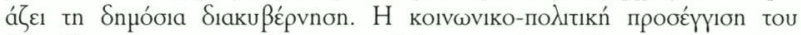

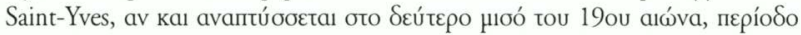

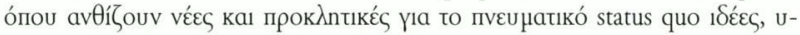

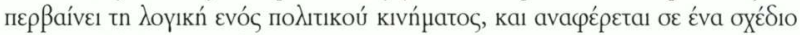

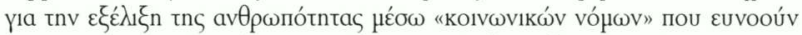

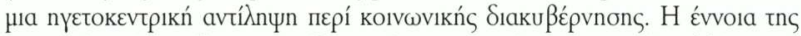

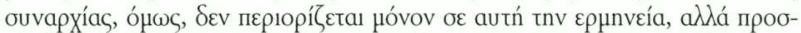

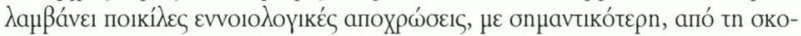

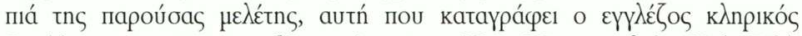

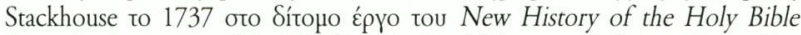
from the Beginning of the World to the Establishment of Christianity, opí̧o-

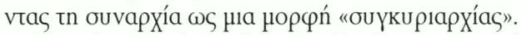

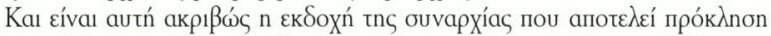

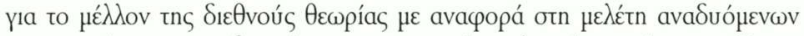

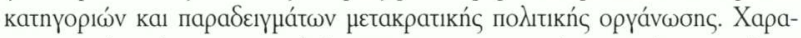

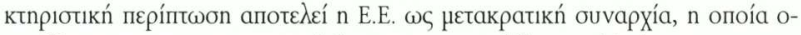

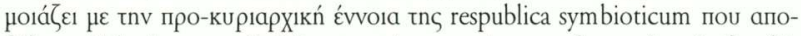

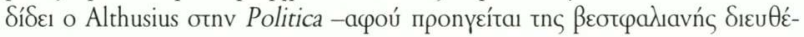




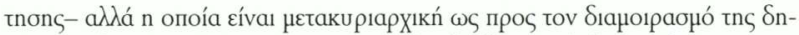

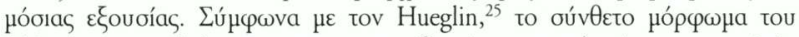

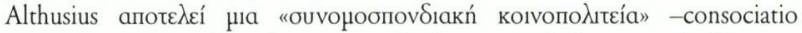

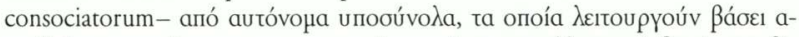

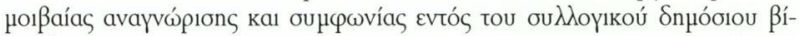

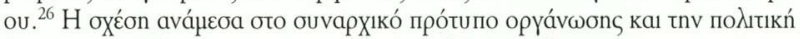

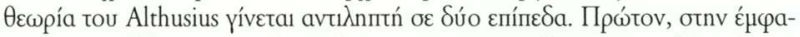

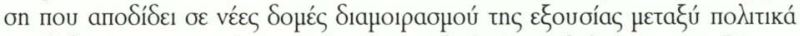

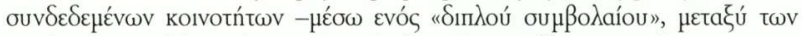

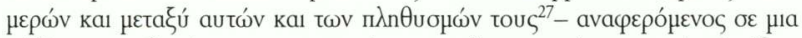

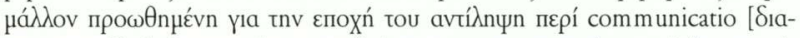

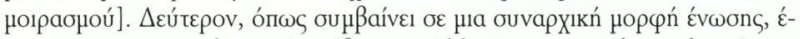

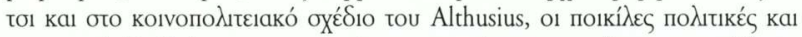

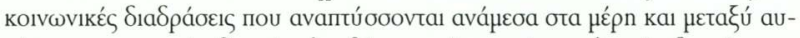

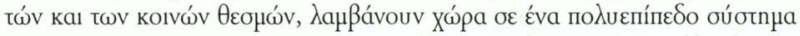

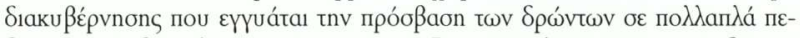

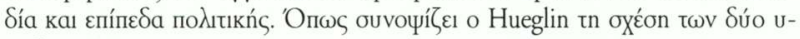

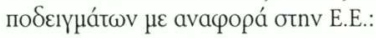

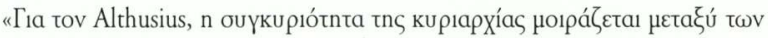

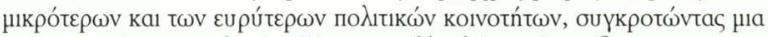

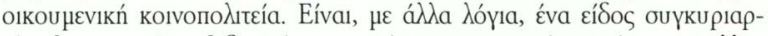

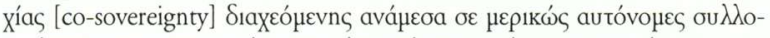

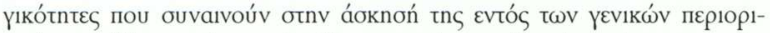

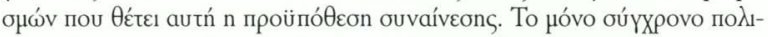

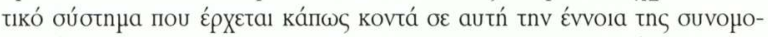

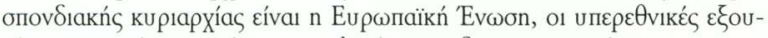

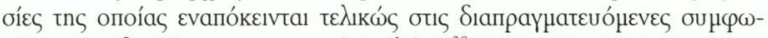

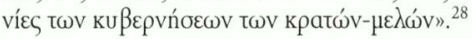

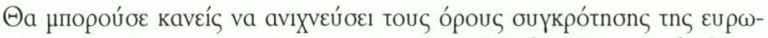

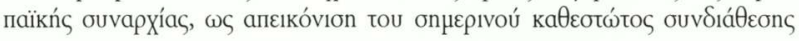

25. T.O. Hueglin, Early Modern Concepts for Late Modern Worlds: Althusius on Community and Federalism, Wilfrid Laurier University Press, Waterloo, On. 1999, б. 5.

26. D.J. Elazar, "Althusius' Grand Design for a Federal Commonwealth", бто J. Althusius,

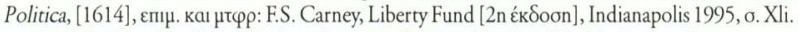

27. T.O. Hueglin, Early Modern Concepts for Late Modern Worlds, ó.n., б. 4.

28. ¿to í́lo. 


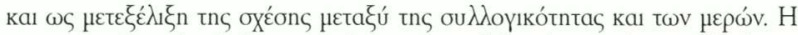

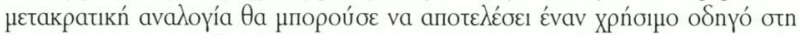

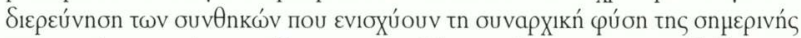

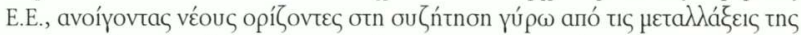

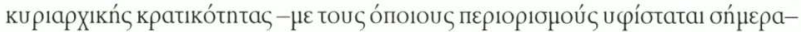

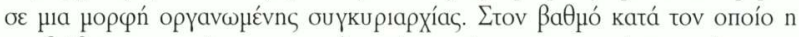

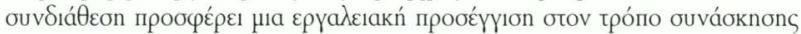

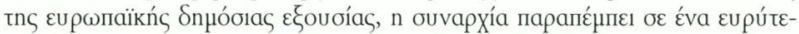

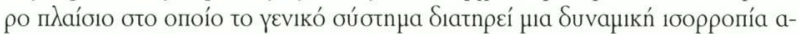

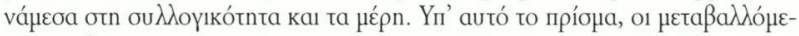

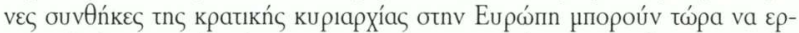

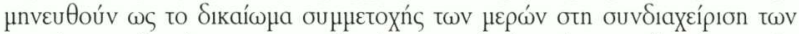

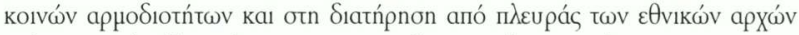

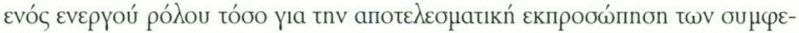

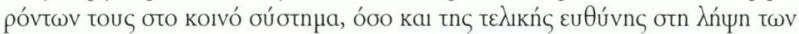

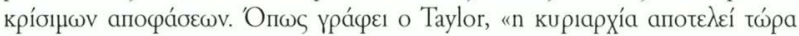

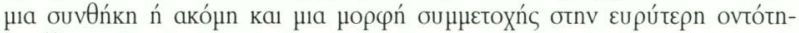

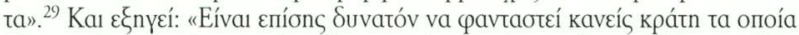

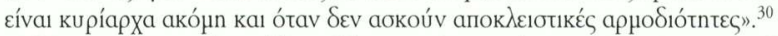

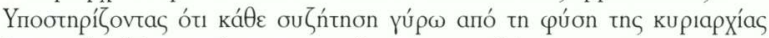

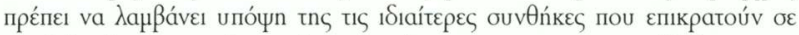

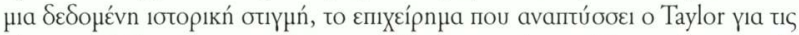

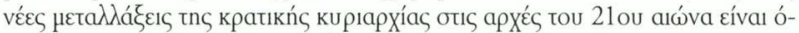

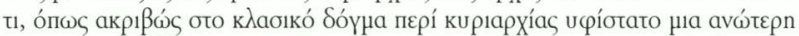

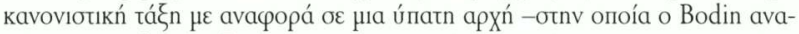

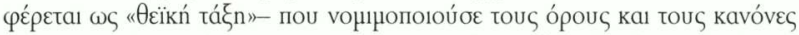

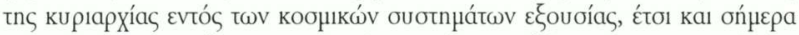

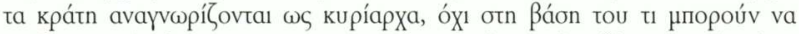

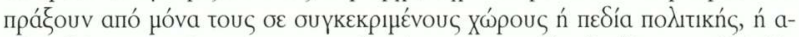

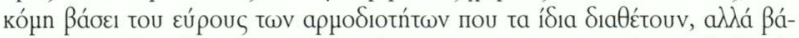

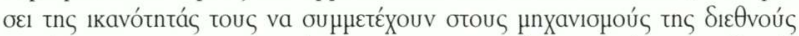

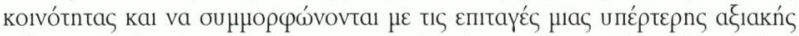

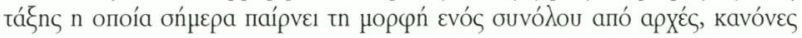

29. P. Taylor, "The United Nations in the 1990s: Proactive Cosmopolitanism and the Issue of Sovereignty», Political Studies, tóp. 47, тx. 3, 1999, б. 560.

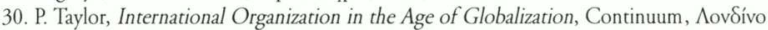
2003, o. 47. 


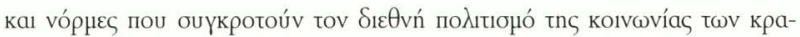

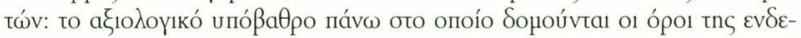

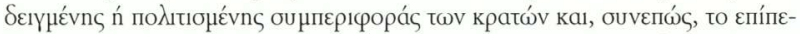

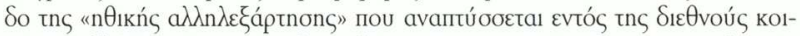

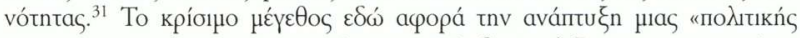

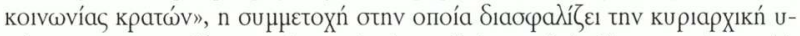

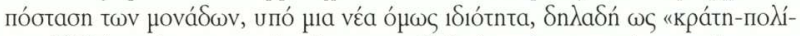

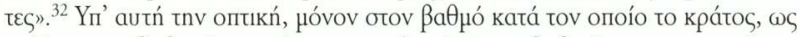

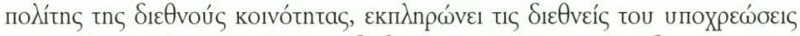

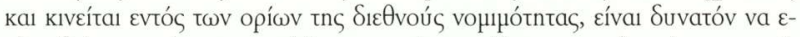

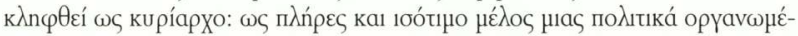

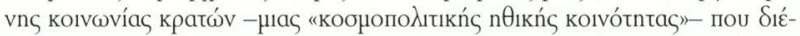

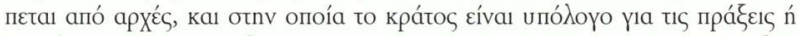

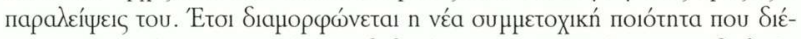

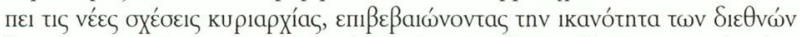

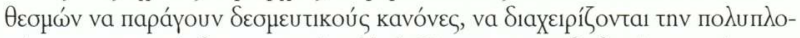

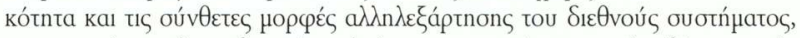

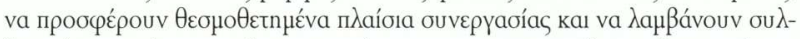

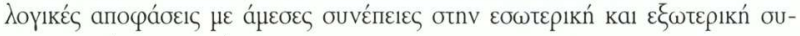

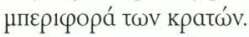

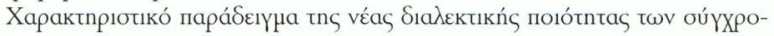

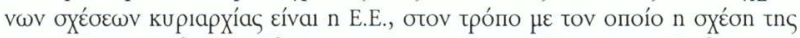

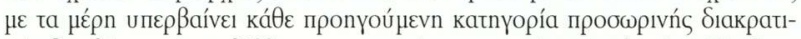

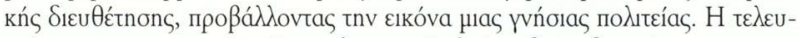

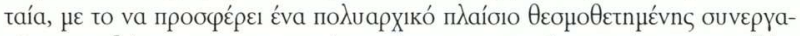

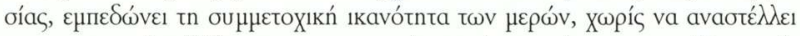

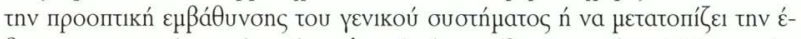

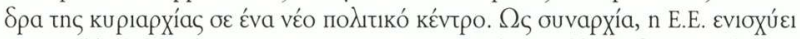

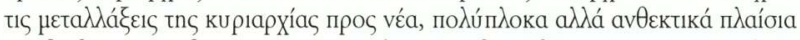

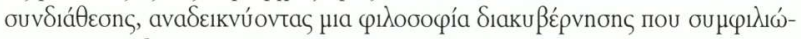

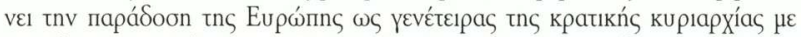

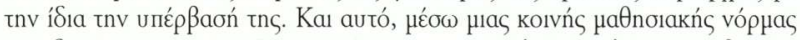

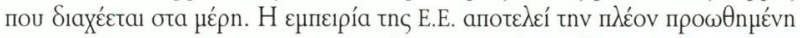

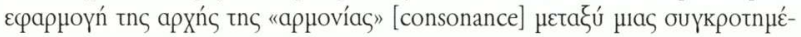

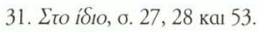

32. ¿то í 


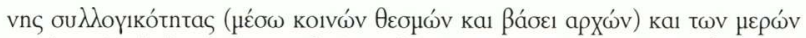

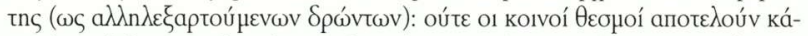

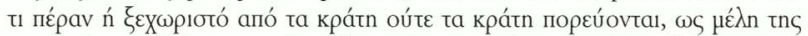

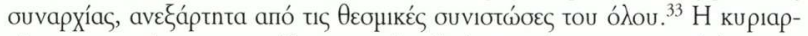

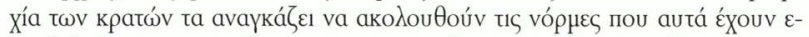

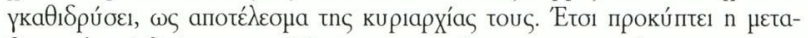

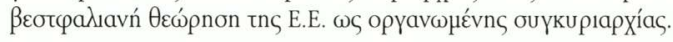

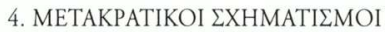

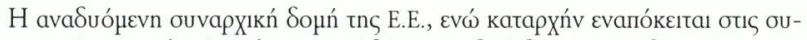

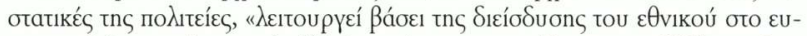

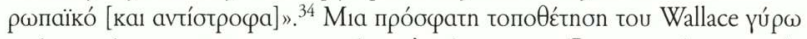

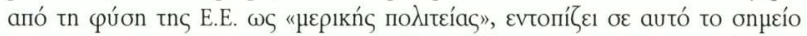

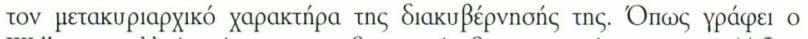

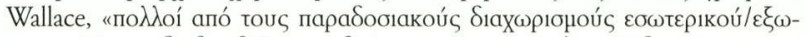

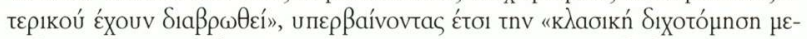

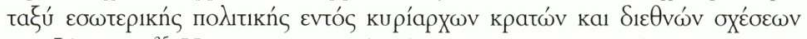

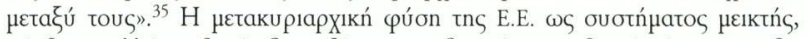

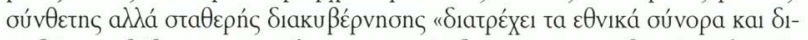

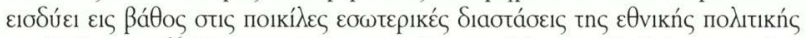

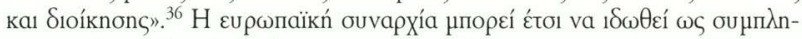

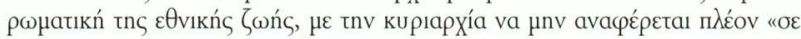

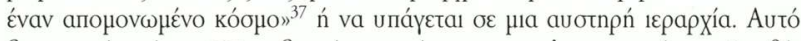

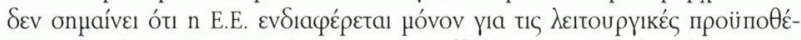

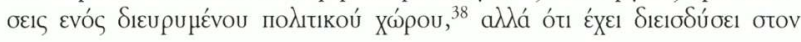

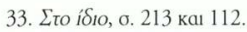

34. B. Laffan, "The European Union: A Distinctive Model of Internationalization", Journal of European Public Policy, tóp. 5, тx. 2, ๘. 242.

35. W. Wallace, "Post-sovereign governance: the EU as a partial polity», oro $\mathrm{H}$. Wallace -

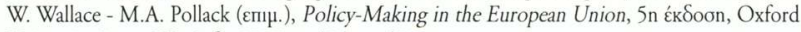

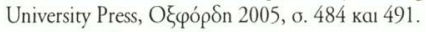

36. ¿тo í́ıı, o. 493.

37. P. Taylor, «The United Nations in the 1990s: Proactive Cosmopolitanism and the Issue of Sovereignty", ó.n., б. 538.

38. Bג. B. Kohler-Koch, "Europe in Search of Legitimate Governance», ARENA Working Papers, no. WP 99/27, 1999. 


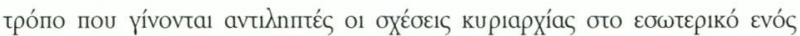

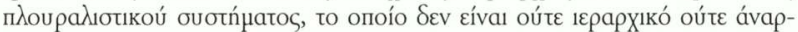

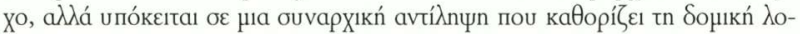

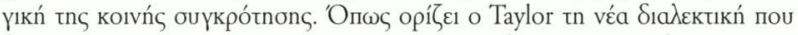

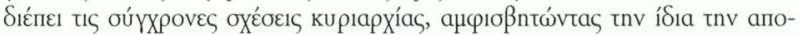

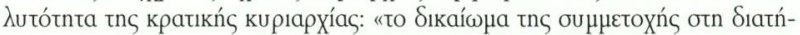

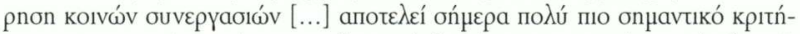

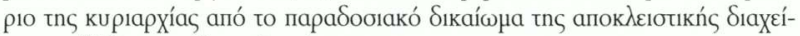

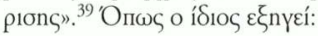

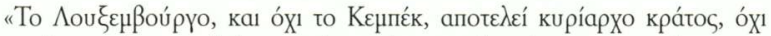

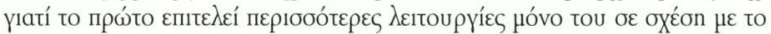

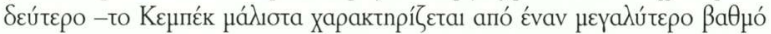

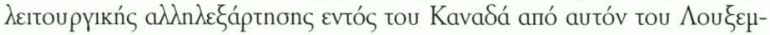

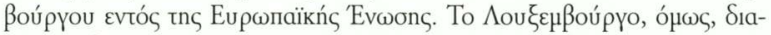

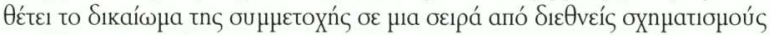

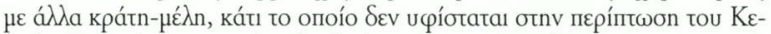

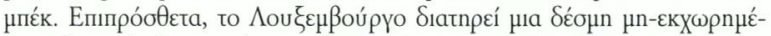

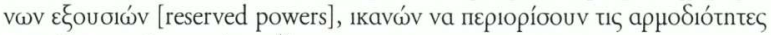

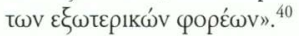

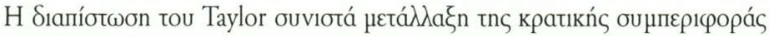

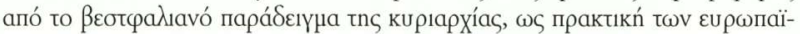

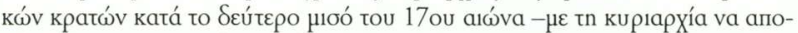

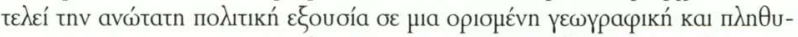

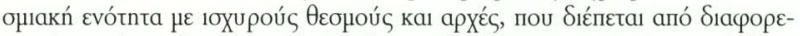

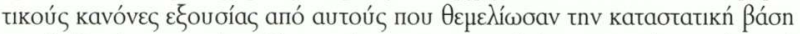

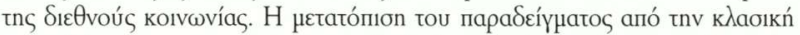

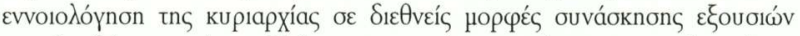

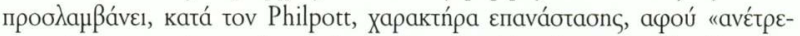

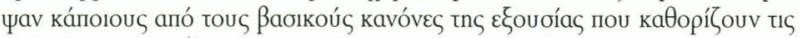

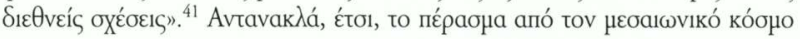

39. P. Taylor, «The United Nations in the 1990s: Proactive Cosmopolitanism and the Issue of Sovereignty", ó.m., о. 564.

40. P. Taylor, International Organization in the Age of Globalization, ó.n., ๙. 53.

41. D. Philpott, Revolutions in Sovereignty: How Ideas Shaped Modern International Relations, Princeton University Press, Princeton 2001, o. 3. 


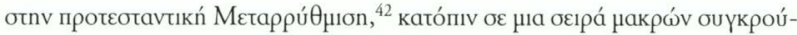

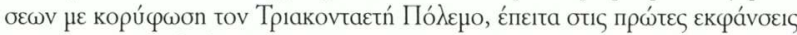

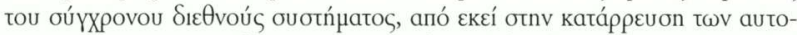

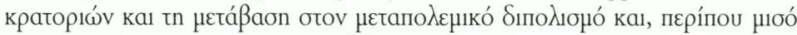

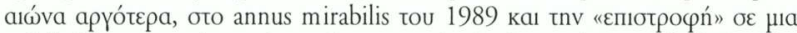


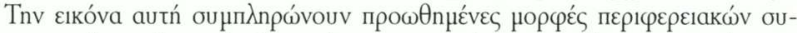

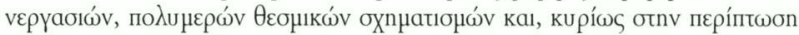

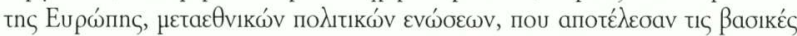

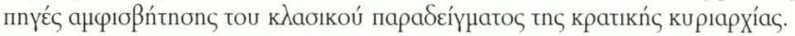

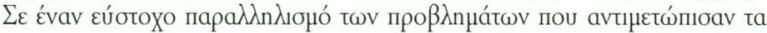

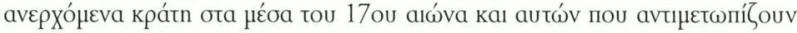

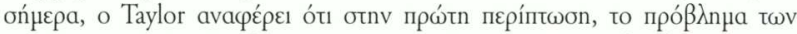

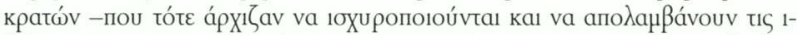

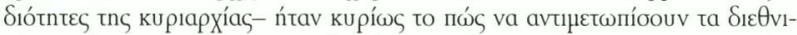

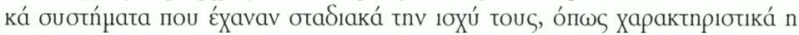

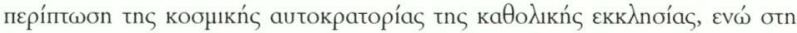

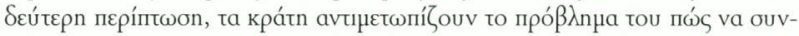

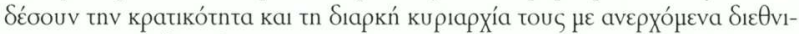

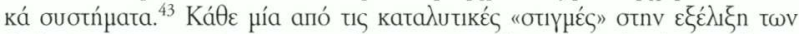

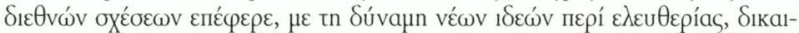

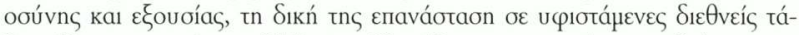

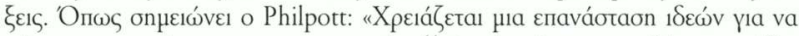

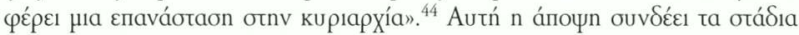

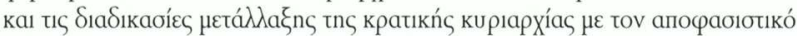

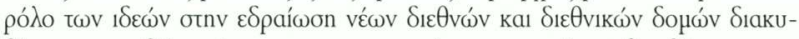

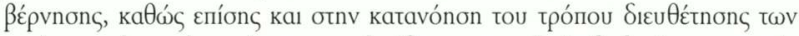

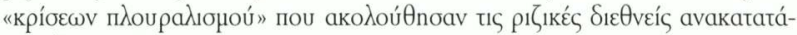

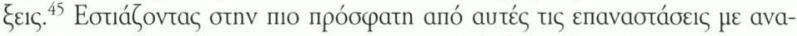

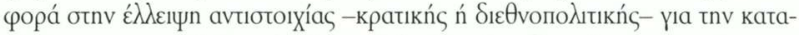

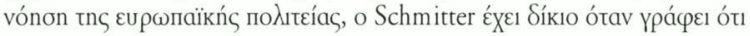

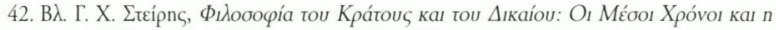

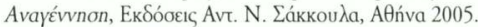

43. P. Taylor, International Organization in the Age of Globalization, ó.п., б. 211-212.

44. D. Philpott, Revolutions in Sovereignty: How Ideas Shaped Modern International Relations, ó.п., о. 4.

45. Eto ísı. 


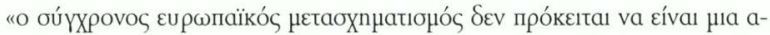

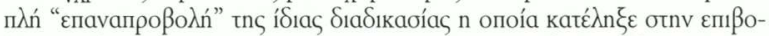

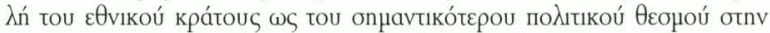

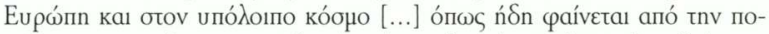

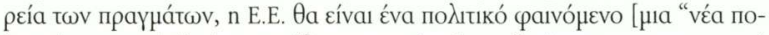

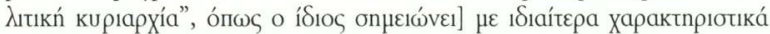
үvopíøuata". ${ }^{46}$

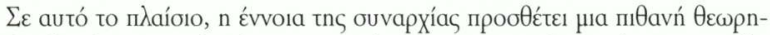

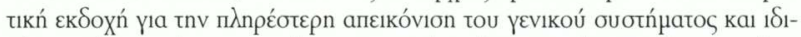

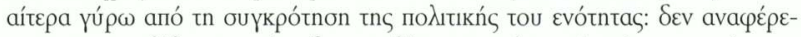

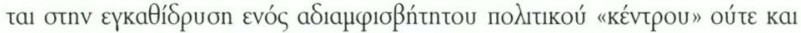

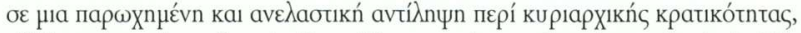

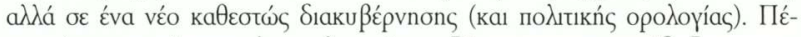

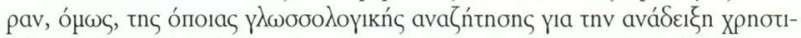

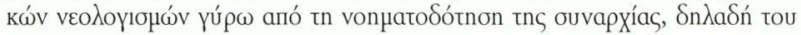

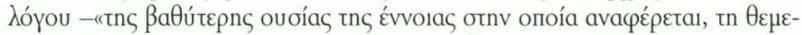
$\lambda ı \omega ́ \delta$ a

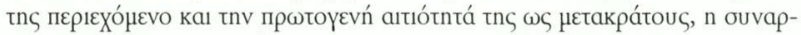

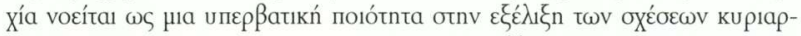

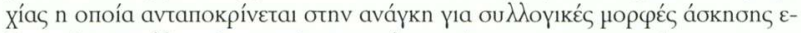

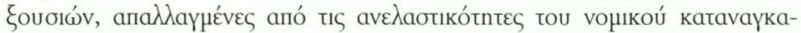

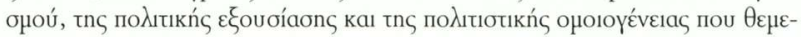

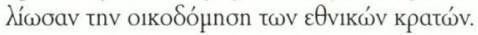

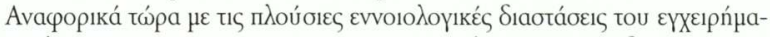

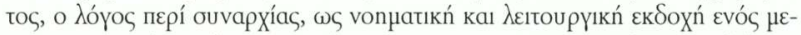

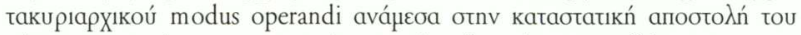

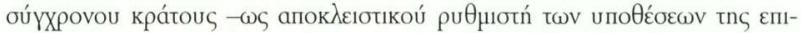

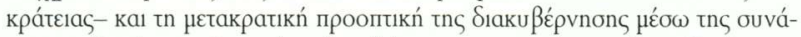

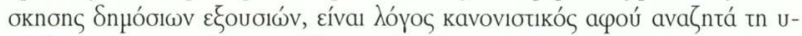

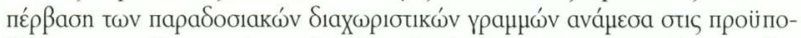

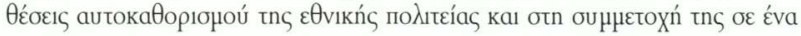

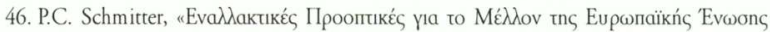

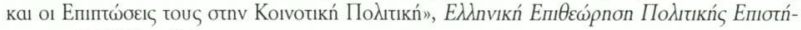

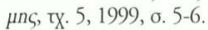

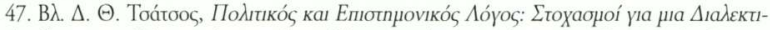

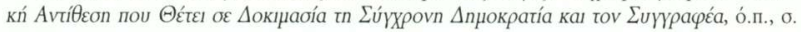
31-32. 


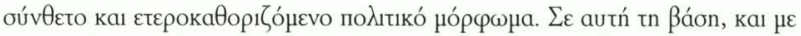

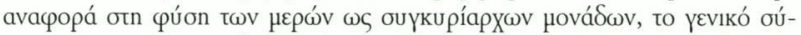

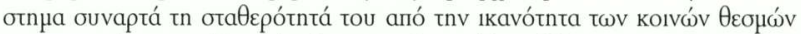

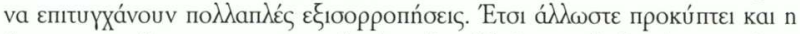

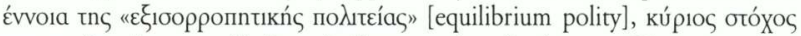

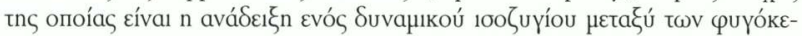

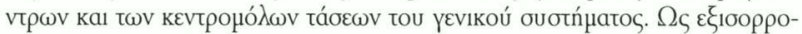

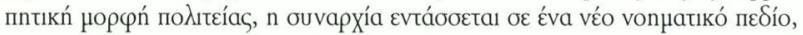

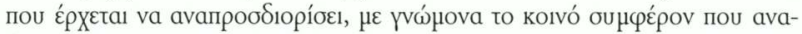

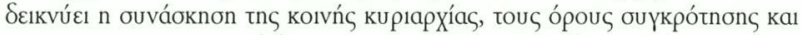

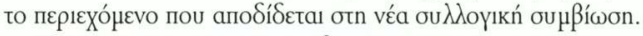

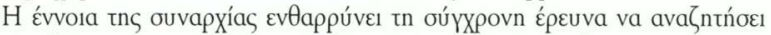

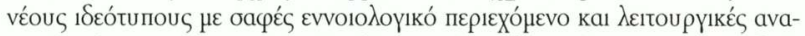

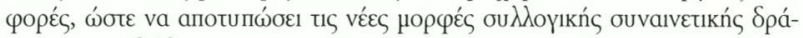

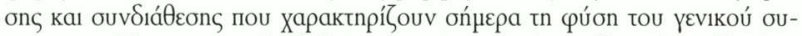

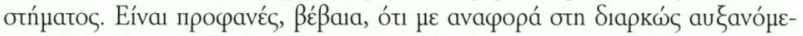

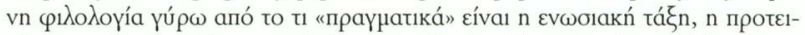

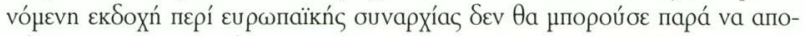

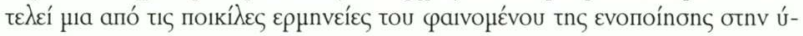

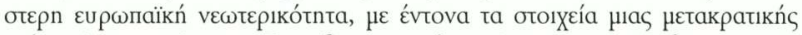

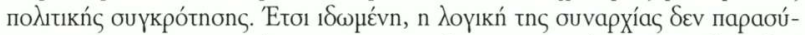

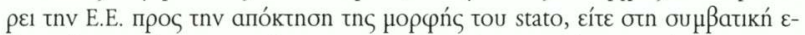

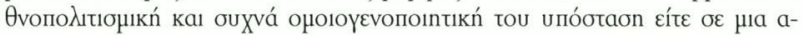

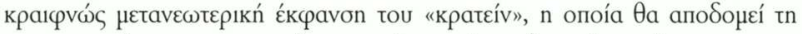

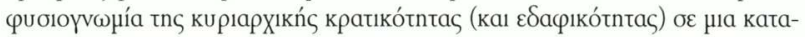

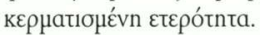

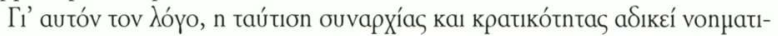

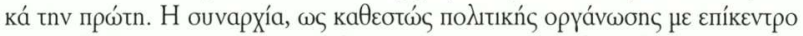

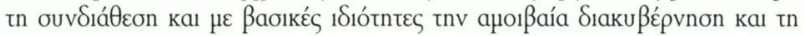

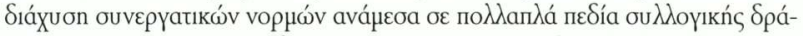

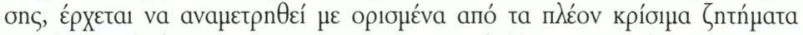

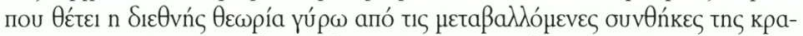

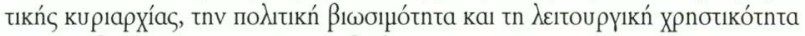

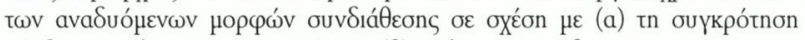

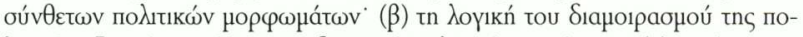

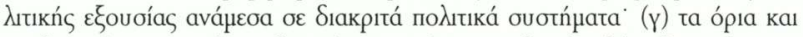

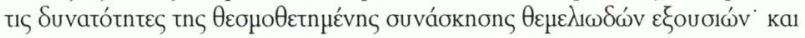




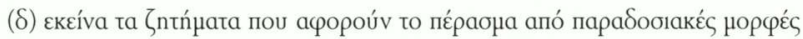

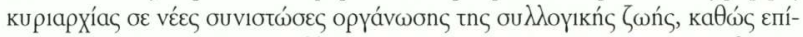

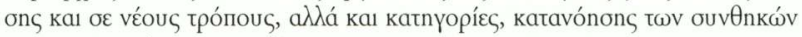

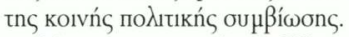

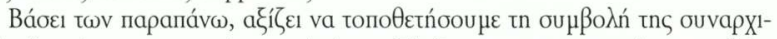

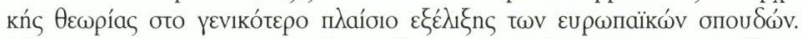

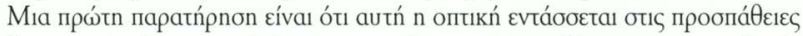

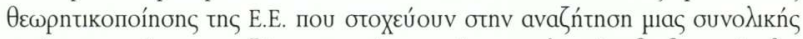

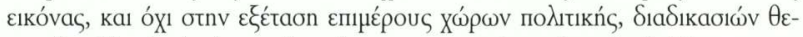

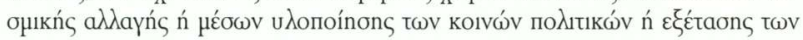
$\varepsilon \theta$ VIK

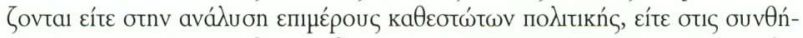

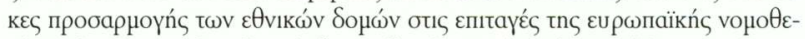

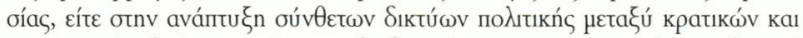

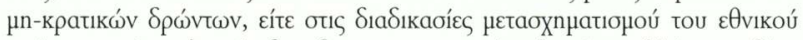

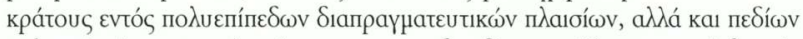

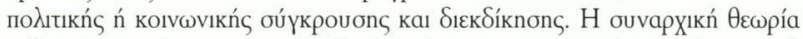

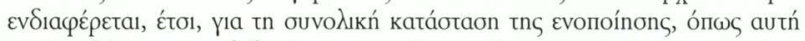

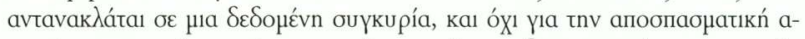

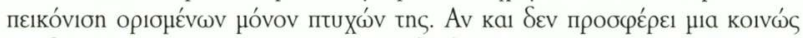

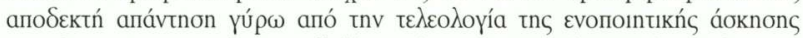

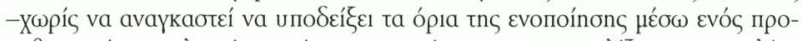

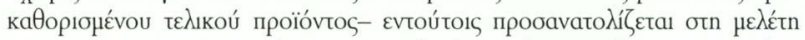

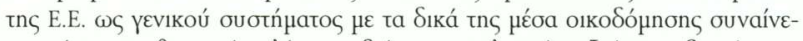

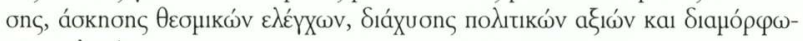

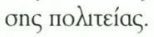

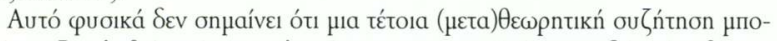

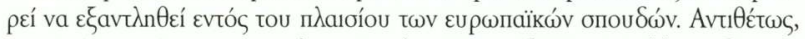

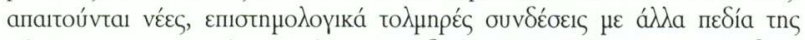

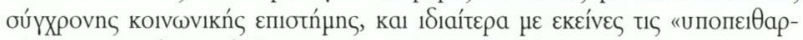

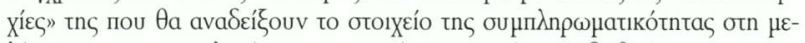

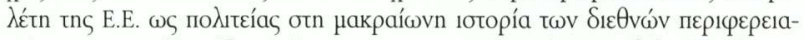

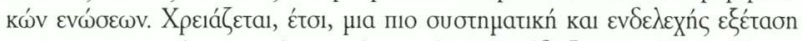

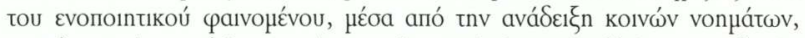

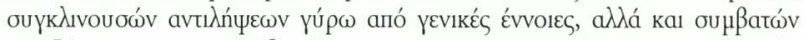

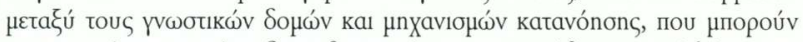

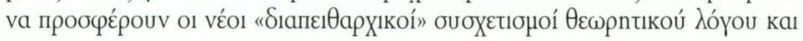




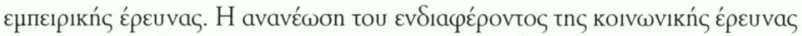

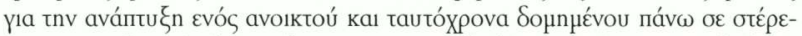

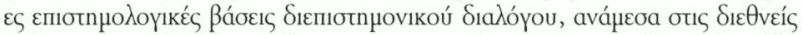

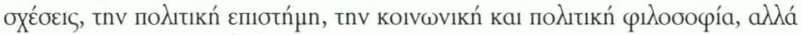

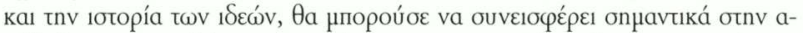

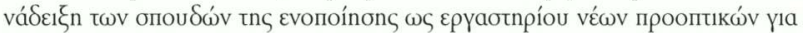

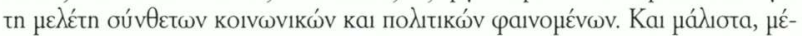

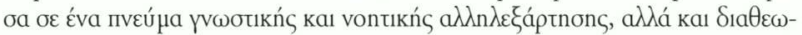

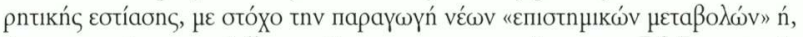

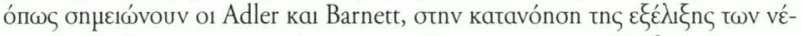

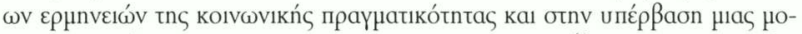

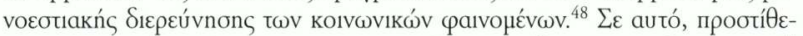

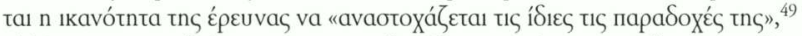

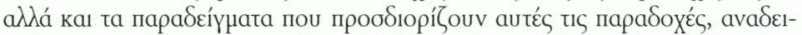

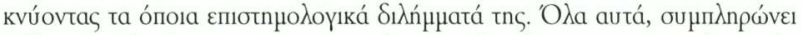

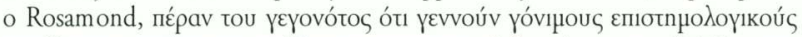

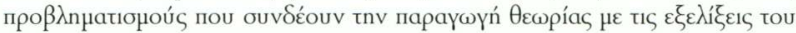

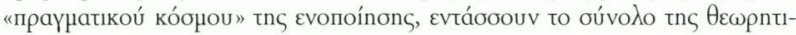

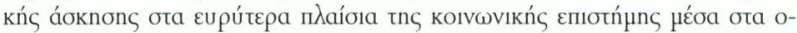

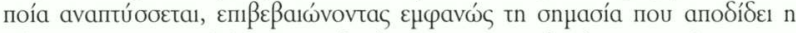

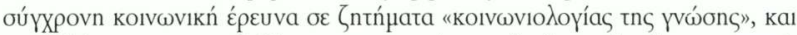

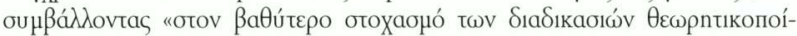
nons". ${ }^{50}$

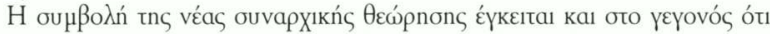

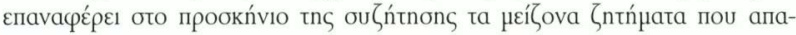

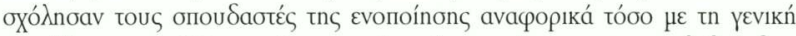

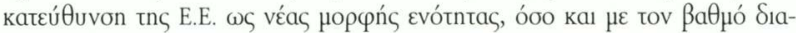

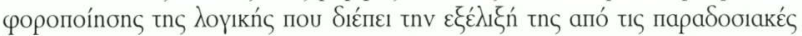

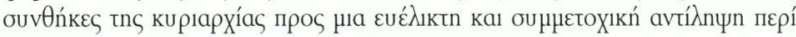

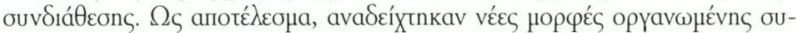

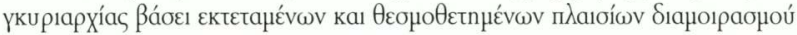

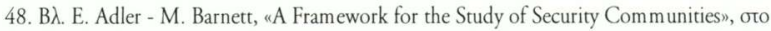
E. Adler - M. Barnett (впц.), Security Communities, Cambridge University Press, Cambridge

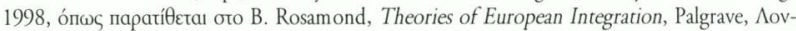
Sívo 2000, б. 170.

49. B. Rosamond, Theories of European Integration, ó.п., б. 191.

50. ¿to ísıo, o. 189 ка 196. 


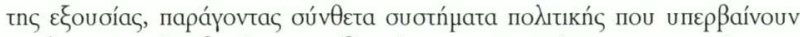

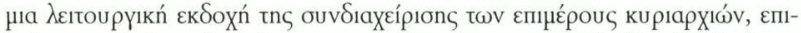

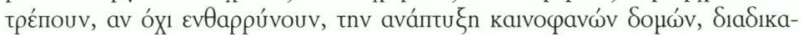

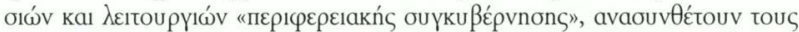

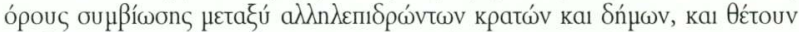

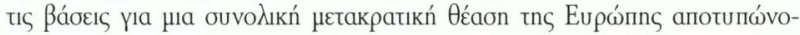

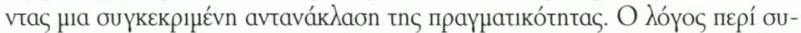

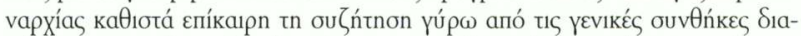

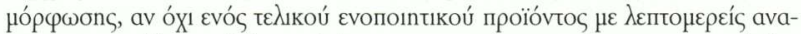

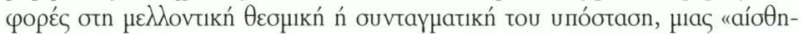

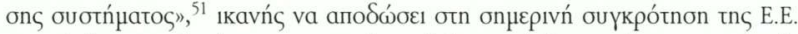

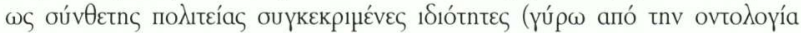

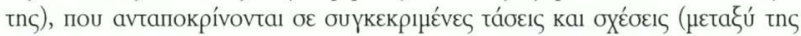

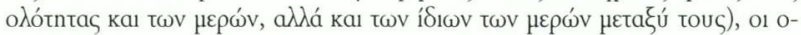

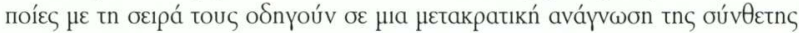

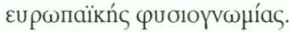

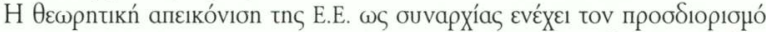

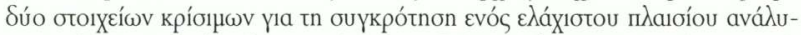

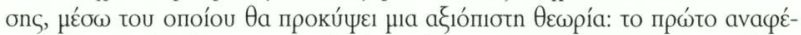

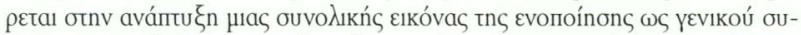

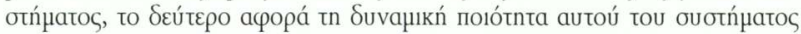

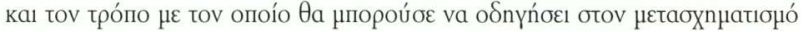

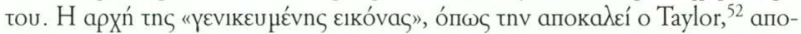

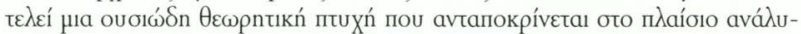

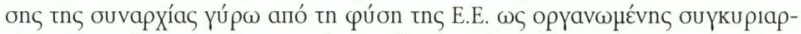

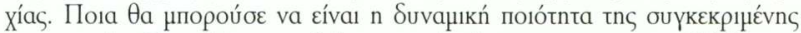

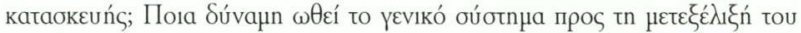

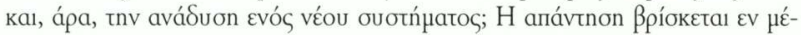

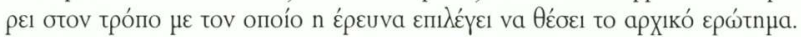

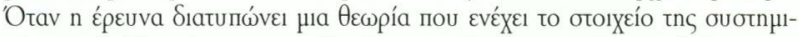

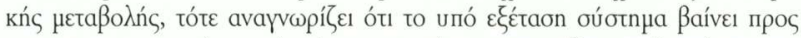

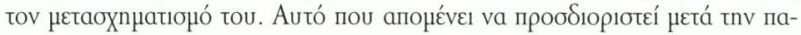

51. P. Taylor, «Integration theory in the early twenty-first century: a setting for disinte-

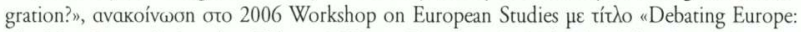

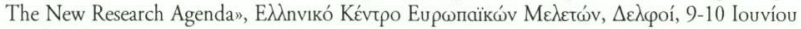
2006, o. 5.

52. ¿тo í́ı, ฮ. 6. 


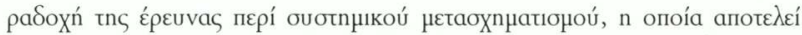

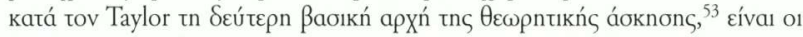

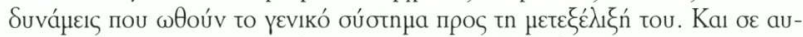

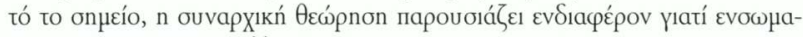

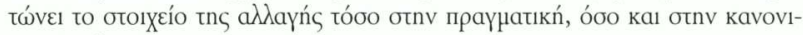

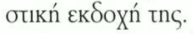

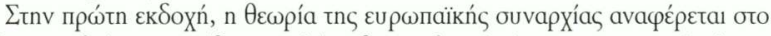

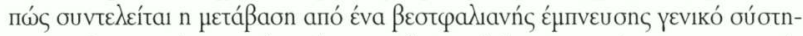

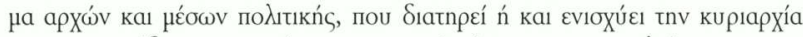

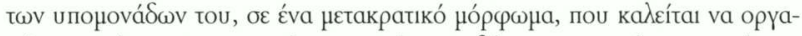

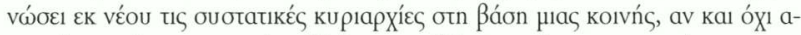

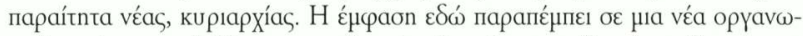

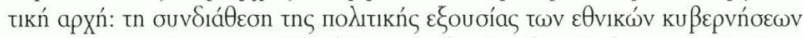

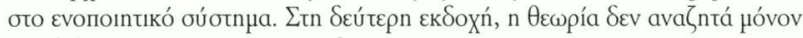

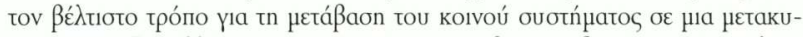

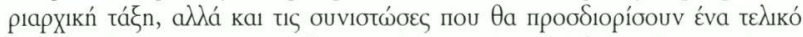

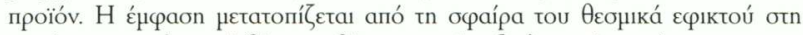

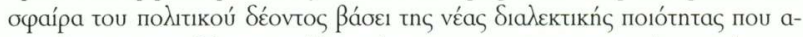

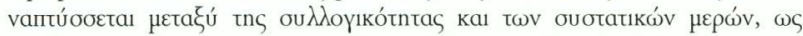

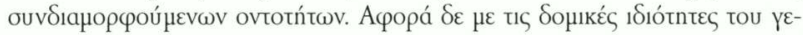

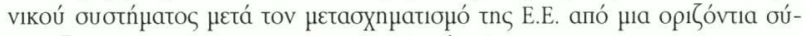
$\mu п \rho а \xi$ n кu

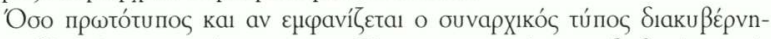

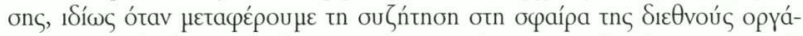

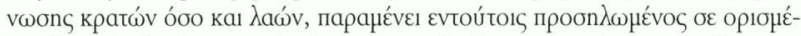

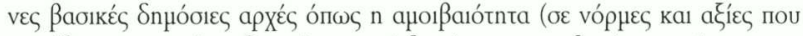

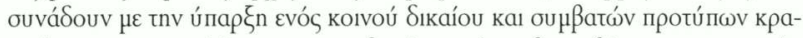

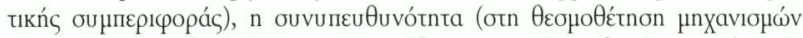

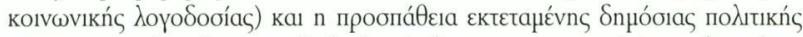

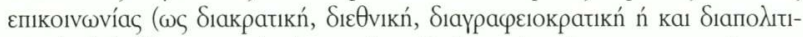

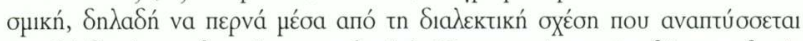

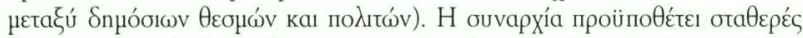

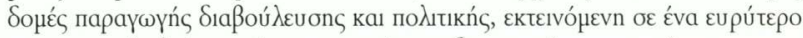

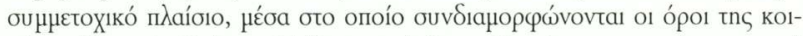

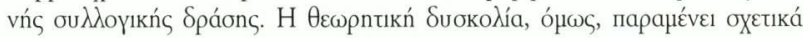




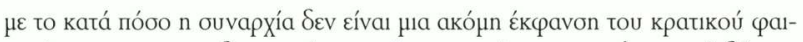

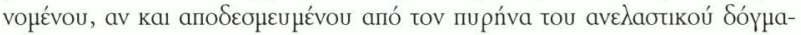

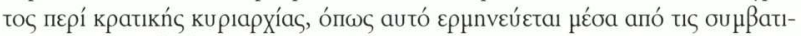

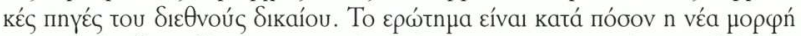

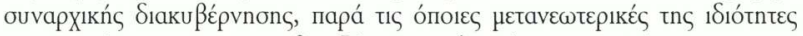

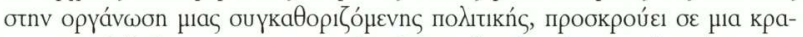

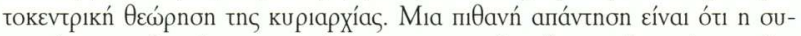

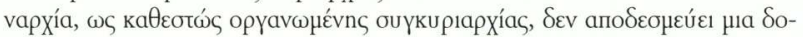

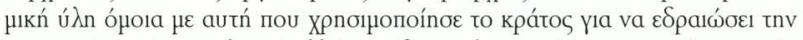

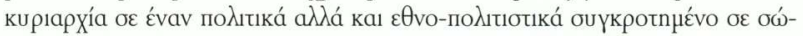

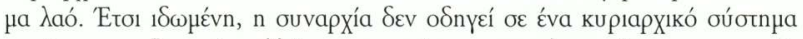

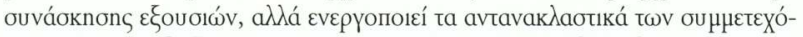

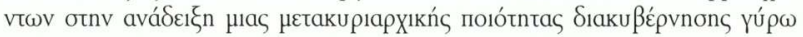

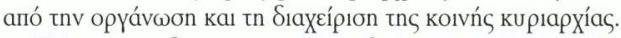

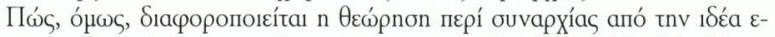
vós -

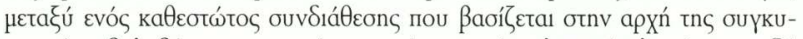

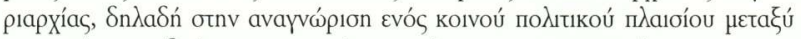

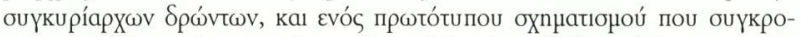

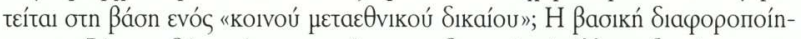

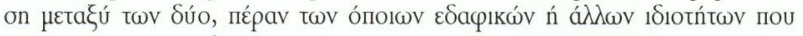

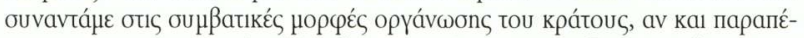

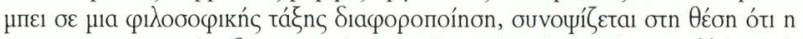

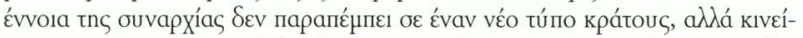

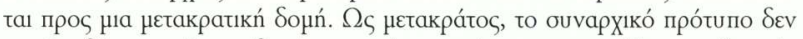

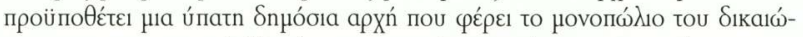

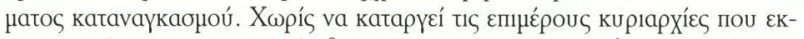

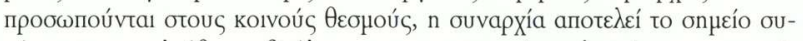

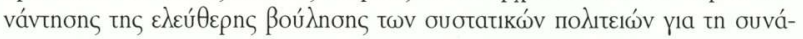

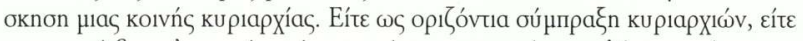

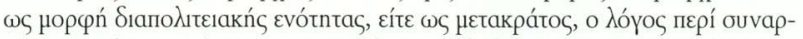

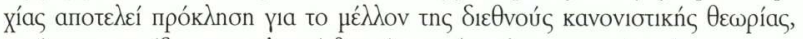

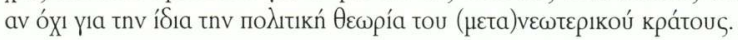




\section{5. $\triangle$ HMOKPATIA KAI YNAPXIA}

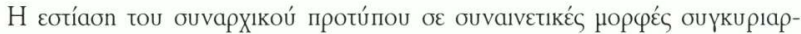

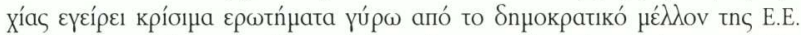

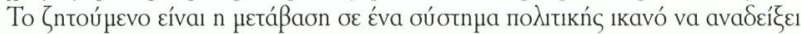

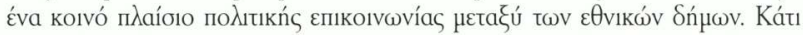

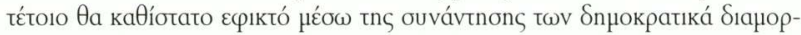

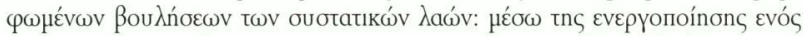

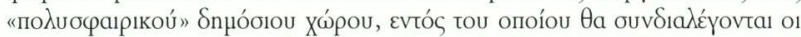

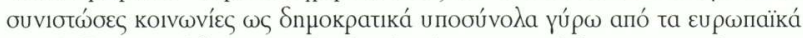

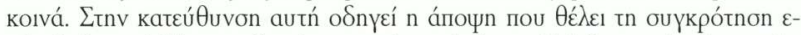

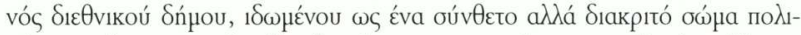

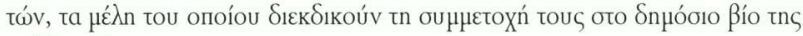

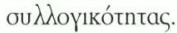

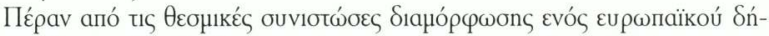

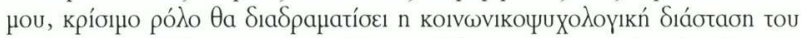

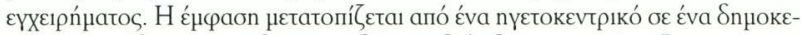

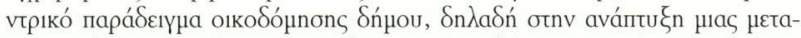

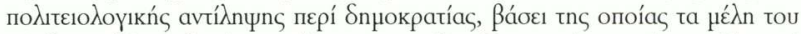

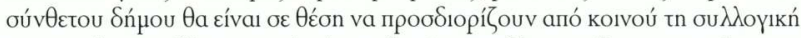

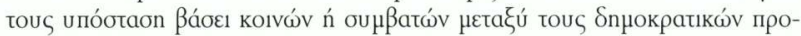

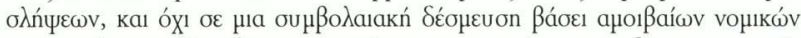

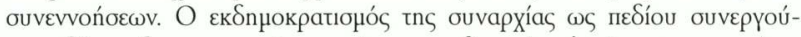

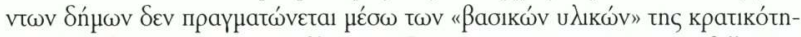

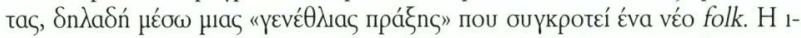

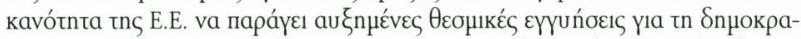

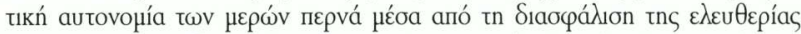

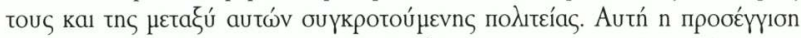

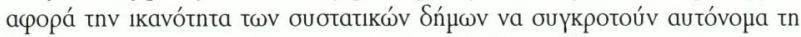

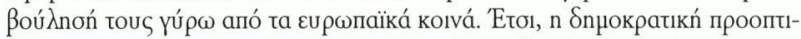

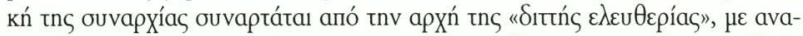

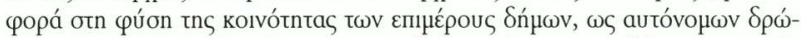

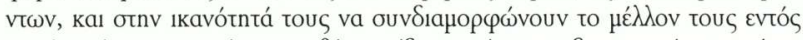

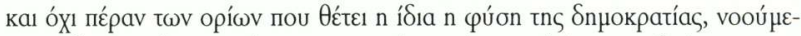

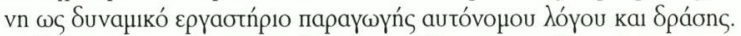

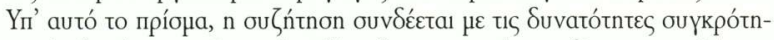

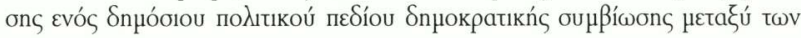




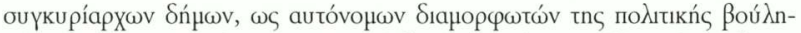

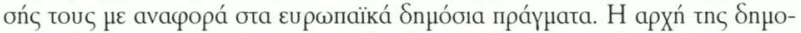

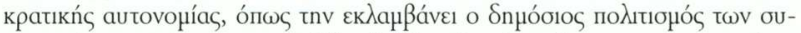

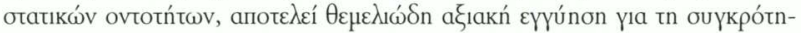

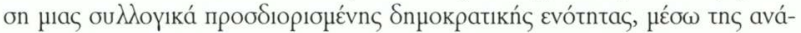

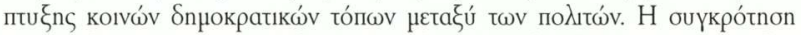

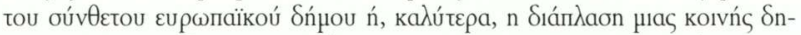

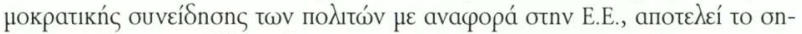

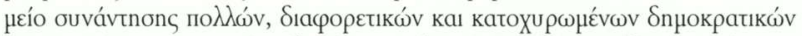

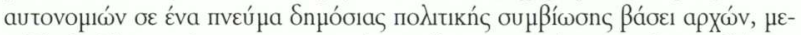

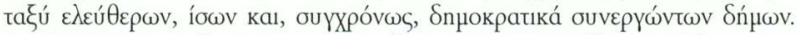

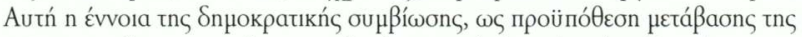

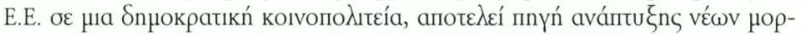

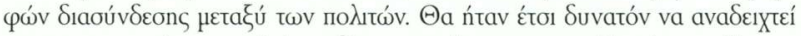

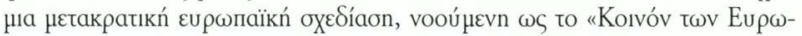

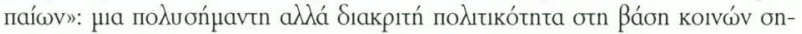

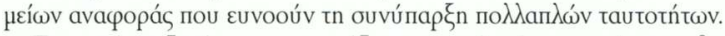

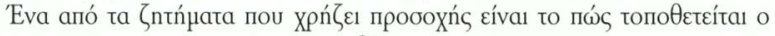

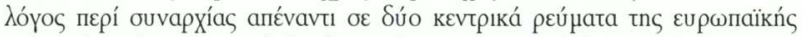

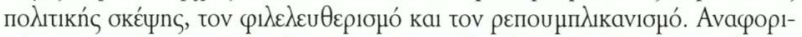

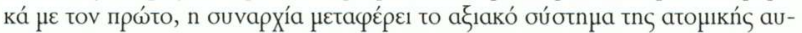

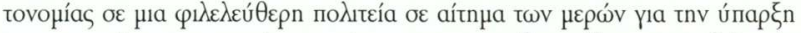

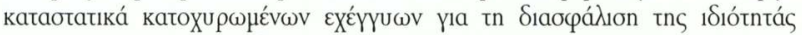

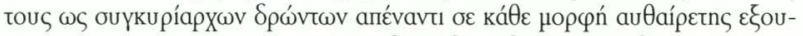

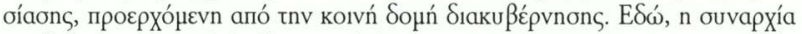

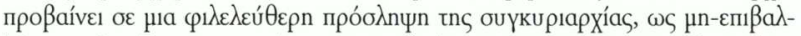

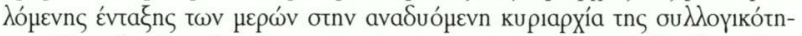

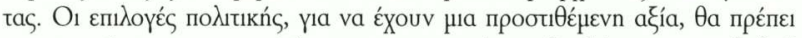

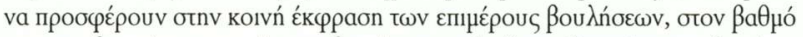

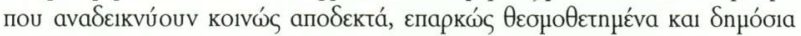

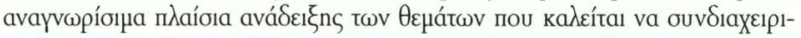

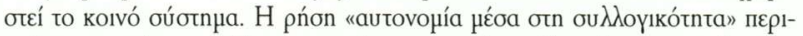

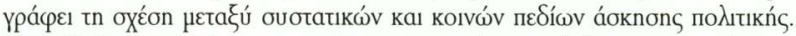

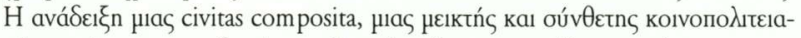

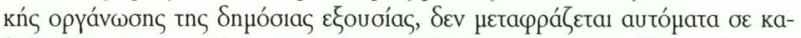

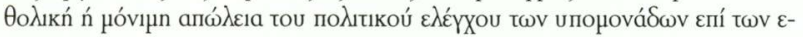
пıкратєı 


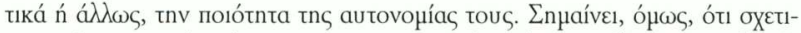

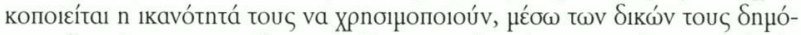

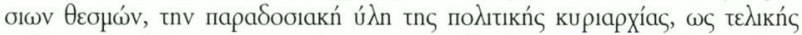

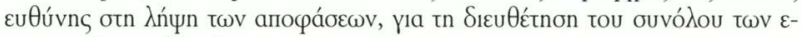

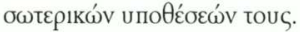

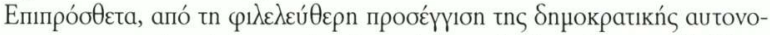

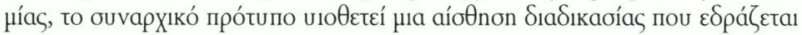

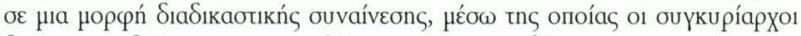

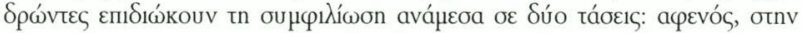

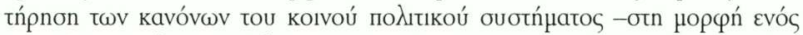

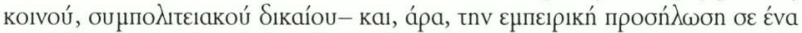

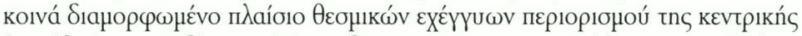

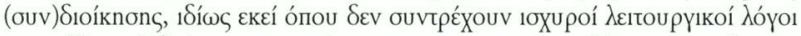

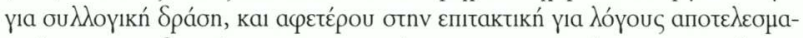

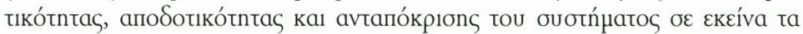

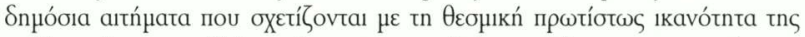

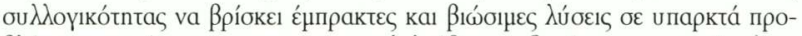

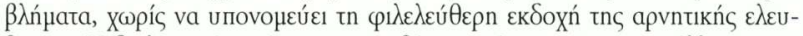

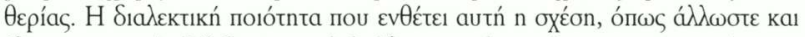

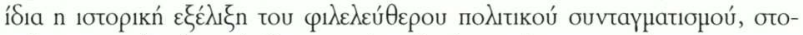

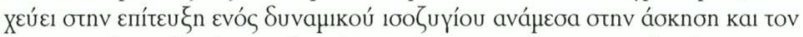

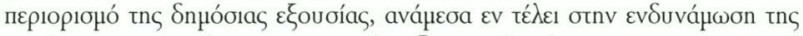

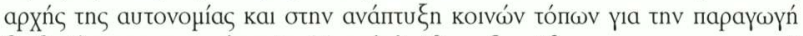

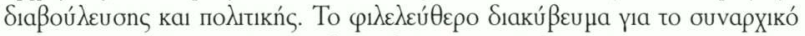

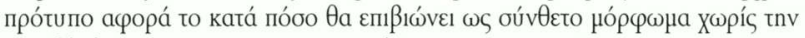

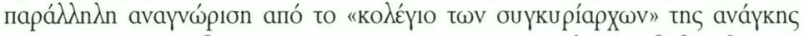

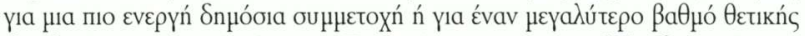

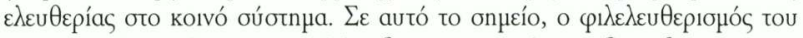

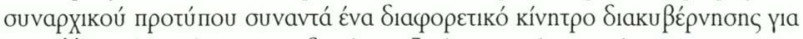

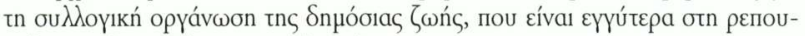

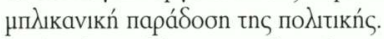

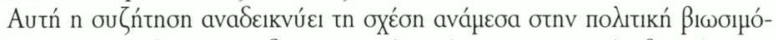

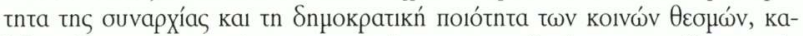

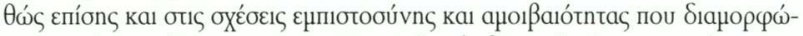

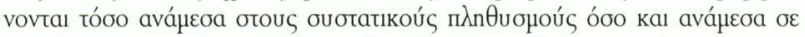

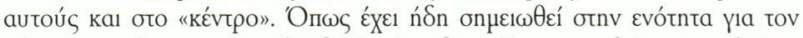
vย́o 


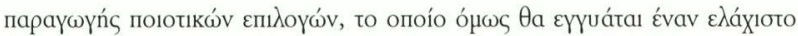

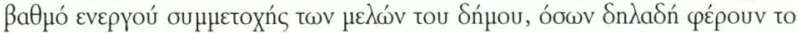

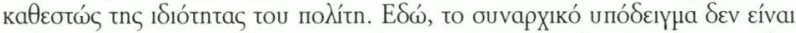

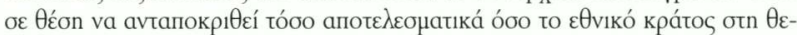

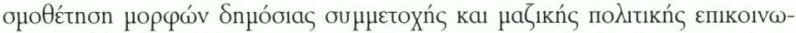

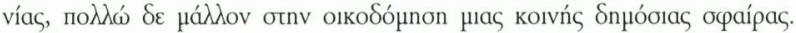

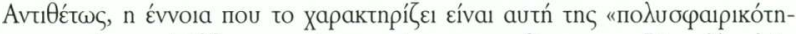

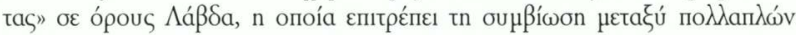

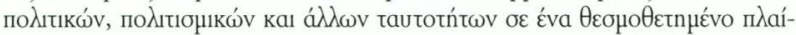

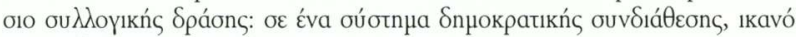

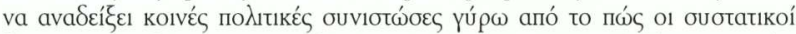

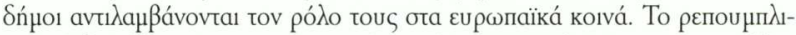

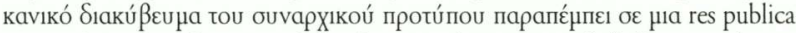

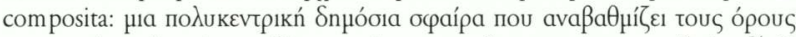

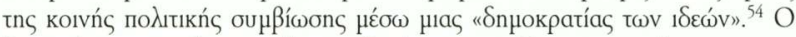

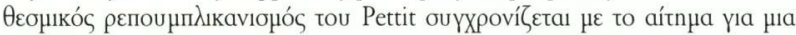

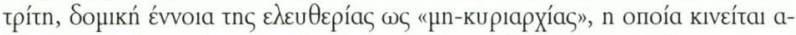

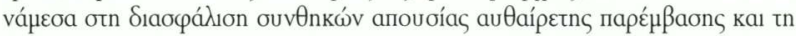

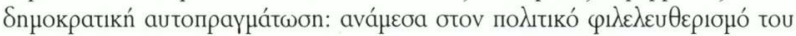

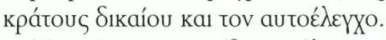

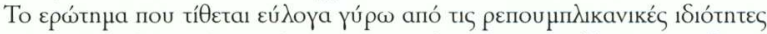

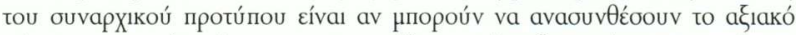

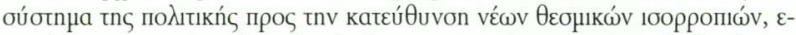

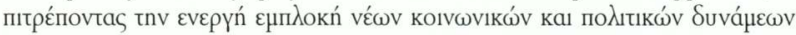

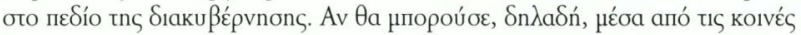

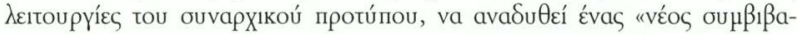

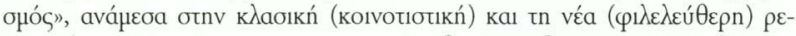

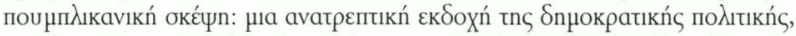

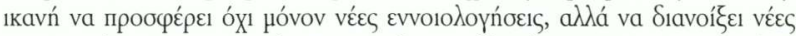

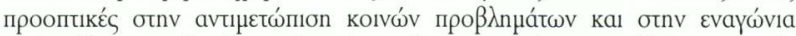

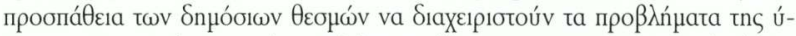

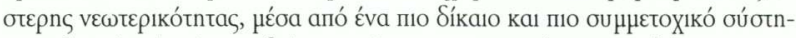

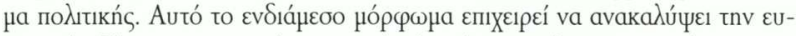

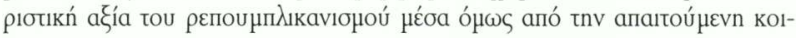

54. P. Pettit, "The Many Meanings of Demos", mimeo, Ioúvios 2005. B $\lambda$. P. Pettit,

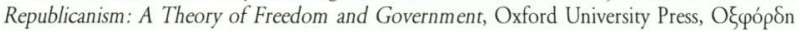
1997. 


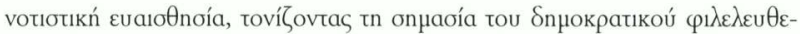

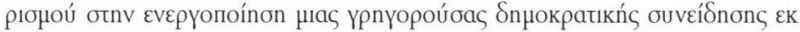

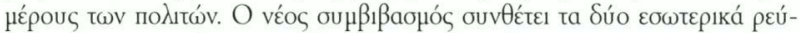

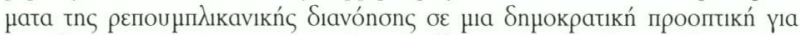

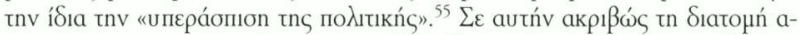

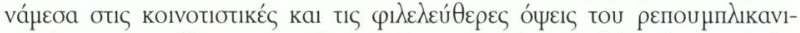

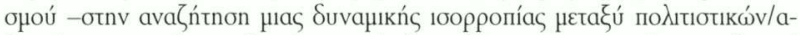

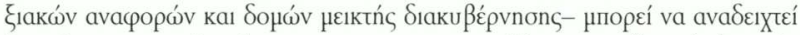

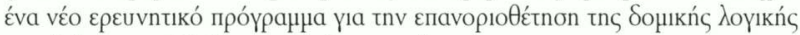

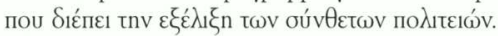

\section{6. ¿YMПЕPA¿MA}

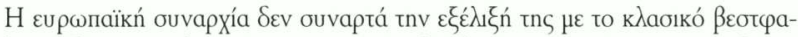

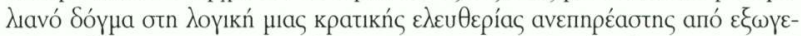

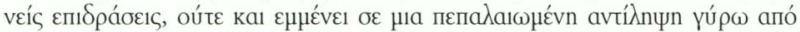

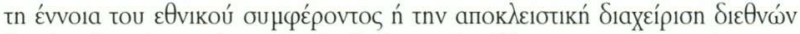

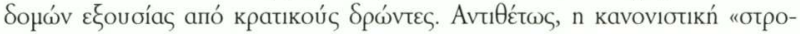

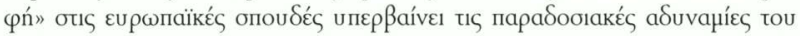

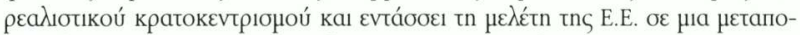

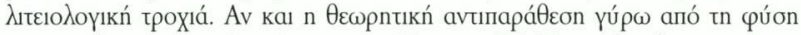

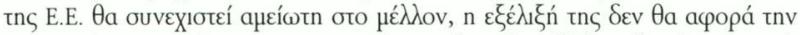

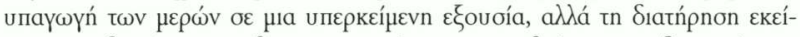

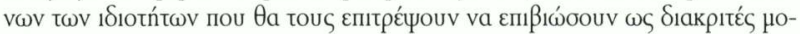

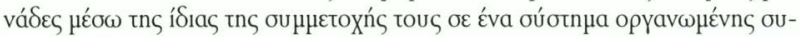
үкupiapXías.

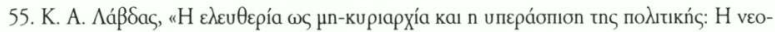

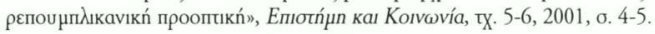

